IZA DP No. 8961

Immigrants' Effect on Native Workers:

New Analysis on Longitudinal Data

Mette Foged

Giovanni Peri

March 2015 


\title{
Immigrants' Effect on Native Workers: New Analysis on Longitudinal Data
}

\author{
Mette Foged \\ University of Copenhagen \\ Giovanni Peri \\ University of California, Davis \\ and IZA
}

\section{Discussion Paper No. 8961 \\ March 2015}

\author{
IZA \\ P.O. Box 7240 \\ 53072 Bonn \\ Germany \\ Phone: +49-228-3894-0 \\ Fax: +49-228-3894-180 \\ E-mail: iza@iza.org
}

\begin{abstract}
Any opinions expressed here are those of the author(s) and not those of IZA. Research published in this series may include views on policy, but the institute itself takes no institutional policy positions. The IZA research network is committed to the IZA Guiding Principles of Research Integrity.

The Institute for the Study of Labor (IZA) in Bonn is a local and virtual international research center and a place of communication between science, politics and business. IZA is an independent nonprofit organization supported by Deutsche Post Foundation. The center is associated with the University of Bonn and offers a stimulating research environment through its international network, workshops and conferences, data service, project support, research visits and doctoral program. IZA engages in (i) original and internationally competitive research in all fields of labor economics, (ii) development of policy concepts, and (iii) dissemination of research results and concepts to the interested public.
\end{abstract}

IZA Discussion Papers often represent preliminary work and are circulated to encourage discussion. Citation of such a paper should account for its provisional character. A revised version may be available directly from the author. 
IZA Discussion Paper No. 8961

March 2015

\section{ABSTRACT}

\section{Immigrants' Effect on Native Workers: New Analysis on Longitudinal Data}

Using longitudinal data on the universe of workers in Denmark during the period 1991-2008 we track the labor market outcomes of low skilled natives in response to an exogenous inflow of low skilled immigrants. We innovate on previous identification strategies by considering immigrants distributed across municipalities by a refugee dispersal policy in place between 1986 and 1998. We find that an increase in the supply of refugee-country immigrants pushed less educated native workers (especially the young and low-tenured ones) to pursue less manual-intensive occupations. As a result immigration had positive effects on native unskilled wages, employment and occupational mobility.

JEL Classification: F22, J24, J61

Keywords: refugees, dispersal policy, manual skills, employment, wages

Corresponding author:

Giovanni Peri

University of California, Davis

One Shields Avenue

Davis, CA 95616

USA

E-mail: gperi@ucdavis.edu

\footnotetext{
"We thank the Economic Policy Research Network for funding this research project and Jakob Roland Munch for helpful suggestions and discussions. Tito Boeri, David Card, Anna Piil Damm, Christian Dustmann, Cedric Jean-Laurent Elie Gorinas, Jim Harrigan, Ethan Lewis, Lawrence Kahn, Søren Leth-Petersen, Hillel Rappoport and three anonymous referees provided useful comments and suggestions.
} 


\section{Introduction}

In this paper we use individual data on Danish workers over the period 1991-2008 to quantify the consequences of an exogenous change in the supply of immigrants on the labor market outcomes of native workers. The administrative data that we use follow over time every single individual in Denmark. Hence, we can analyze different outcomes over time, control for unobserved individual characteristics and allow for heterogeneous effects. The immigration flows that we consider combine a refugee dispersal policy, in place in Denmark between 1986 and 1998 and designed to distribute immigrants without regard to their preferences and economic considerations, and large inflows of immigrants from countries suffering from crises. These features allow us to build a credible and new identification strategy. This way we can make important progress in assessing the key causal questions in this literature: Do less educated immigrants displace similarly skilled native workers reducing their employment opportunities and wages? Or do they complement native skills, stimulate natives' specialization and increase their opportunities and wages?

Studies of the effect of immigration on native labor market outcomes are abundant. ${ }^{1}$ Their ability to convincingly measure the causal effect of immigrants on natives are limited, however, by two factors. First, genuinely supply-driven changes of the inflow of immigrants are hard to find, especially in the variation across local labor markets within a country. Immigrants, in fact, respond to labor demand by moving to growing regions and leaving stagnating ones. Second, tracking the short run and long run response of native workers' outcomes is hard due to limited availability of nationally representative individual panel data that span several years. Most studies have therefore opted for constructing average outcomes in regions (or region-skill "cells") over time using repeated cross sectional data. This, however, results in combining the effects on incumbents and on those who selectively move into those regions, and it misses the effects on those who selectively move out. This paper makes significant progress on both fronts by improving on identification and by following in the short and long run individual responses to immigrants and by comparing these findings with average area effects.

The immigration flows that we consider are those of people from eight "refugeecountries" into Denmark. We define these countries as those with a large number of

\footnotetext{
${ }^{1}$ Recent surveys of the literature are Longhi, Nijkamp, and Poot (2005); Blau and Kahn (2012); Lewis and Peri (2015).
} 
international refugees in the considered period. They include Bosnia, Afghanistan, Somalia, Iraq which were hit by major crises between 1995 and 2003 and also Iran, Vietnam, Sri Lanka and Lebanon. The distribution of these immigrants and of all refugees (including those from other countries) across municipalities in Denmark was implemented, between 1986 and 1998, following the Spatial Dispersal Policy (Damm, 2009). This policy allocated refugees to spread their burden across municipalities and to create self-supporting enclaves. The authority in charge (Refugee Council) did not even know the economic characteristics and preferences of the immigrants and distributed them as public housing became available in different municipalities. After 1994 a sequence of international crises and wars, beginning with the war in Former Yugoslavia in 1992-95 produced large waves of immigrants from those refugee countries. Those events provide a supply-driven flow of immigrants who, especially after 1998, when the dispersal policy was abandoned, settled where their family sponsors were located. ${ }^{2}$ Therefore the later distribution of these immigrants mirrored the early distribution which was produced by the dispersal policy alone and hence was independent of local labor demand. Using a dispersal policy as a "quasi-experiment" in this literature is new. While few studies have used dispersal policies of immigrants to obtain identification, most of them (e.g. Edin, Fredriksson, and Åslund, 2004; Damm, 2009; Gould, Lavy, and Paserman, 2004) have used them to analyze their effects on outcomes of immigrants. Only Glitz (2012) among the papers we know uses an immigration dispersal policy (in Germany) to identify the labor market effects on natives. ${ }^{3}$

With respect to the outcomes, our analysis is innovative in that it can track three types of variables, both individually and for areas, in the short and in the long run. We analyze for native workers the complex and manual content of tasks performed on the job, the hourly wage compensation and the time worked in a year. We also use two different types of empirical approaches. First, in a classic twostage least squares (2SLS) panel estimation, we absorb most confounding factors in a very large set of fixed effects and use variation of each individual's outcomes in response to refugee-country immigrants in the municipality, instrumented by a

\footnotetext{
${ }^{2}$ By law the sponsor needed "adequately sized accommodation" for the re-unified family. In practice this meant that, at least initially, new family members lived at the same address as their sponsor.

${ }^{3}$ In that study, however, the author does not observe individual outcomes, he can only consider a period of 5 years (1996-2001), he can only exploit small cross sectional variation because of the design of the dispersal and he only analyzes wage and employment outcomes, and not occupation upgrading and mobility.
} 
constructed measure based on the dispersal policy. Second, and more novel to this literature, by exploiting the surge in refugee-country immigration beginning in 1995 we adopt a difference-in-differences approach. We leverage the differential exposure of less educated native workers to refugee-country immigrants based on their 1994 municipality of residence. We follow cohorts of natives that were more or less exposed to immigrants based on their 1994 location and so we identify the effect of differential exposure.

The reason for focussing on less educated natives in most of our analysis is that refugee-country immigrants were largely concentrated among non-college educated individuals, they usually spoke Danish language at low levels of proficiency and they were employed typically in occupations with high manual content and low complexity (as we will define more precisely below). ${ }^{4}$ Hence, they were most likely to compete in the labor market with less educated Danish workers, especially those in manual-intensive occupations. The canonical model implies that an increase in supply of these immigrants worsens the employment and wage prospects of less educated natives, as they compete with each other. However, more recent models (e.g. Ottaviano and Peri, 2012; Peri, 2012; Card, 2009) have emphasized the role of complementarity within education groups as well as upgrading and specialization of native workers in response to immigrants and have found null or positive wage effects for less educated natives. Our paper can provide evidence in favor of one or the other model.

Our analysis has three main findings. First, the increase in refugee-country immigrants pushed less educated native workers to change occupation. This move was significant and towards non-manual occupations, and particularly strong when workers changed establishment. Second, less educated natives experienced positive or null wage effects and positive or null employment effects. Enhanced occupational mobility was partly the reason for these positive effects, complementarity may have also played a role. Third, as we compare a cohort-based analysis and an area-based analysis we find that the direction and magnitude of the effects on native outcomes are similar using either method and the wage and specialization effects persist in the long run. This finding dispels the claim that estimates from the area analysis are uninformative or significantly biased.

\footnotetext{
${ }^{4}$ Asylum seekers are not in our data and not allowed to work in Denmark. Once (if) their case has been approved they will be assigned to an address under the dispersion policy and allowed to work; i.e. they formally enter the country as refugees this date.
} 
This paper is related to several lines of research. We already mentioned the traditional studies on the labor market effects of immigrants and the few examples that use dispersal policies for identification, in particular Glitz (2012). Going beyond the advances in identification, recent studies have also suggested departures from the canonical framework in rationalizing the finding that immigration may have a positive effect on native labor market outcomes: Workers have skills that differ systematically between immigrants and natives; ${ }^{5}$ immigrant labor generates the possibility of specialization with positive efficiency effects; ${ }^{6}$ investment and technology are adjusted by firms to absorb immigrant labor in local markets in the most efficient way. ${ }^{7}$ Our paper provides further evidence in favor of these theories. ${ }^{8}$ By improving on the identification strategy, by tracking the dynamics of these effects, and by following individuals and areas we provide a very robust picture consistent with native upgrading, immigrant-native complementarity and persistent positive effects. ${ }^{9}$

Related to our research are also papers that use similar Danish data. MalchowMøller, Munch, and Skaksen (2012) employ variation within establishment-worker spells to analyze the correlation of immigrant supply with wages of native coworkers. Malchow-Møller et al. (2013) analyze the impact of immigrant hiring on firm's job creation in the farm sector. Malchow-Møller, Munch, and Skaksen (2011) look at the Danish preferential tax scheme for foreign professionals and estimate the effect of hiring them on wages and productivity within the firm. Parrotta, Pozzoli, and Pytlikova (2014) look at the effect of an ethnically diversified workforce on firm productivity. All these papers use more traditional identification strategies that do not rely on the dispersal policy. Finally Hummels et al. (2014) estimate the effects of increased offshoring on wages in manufacturing firms using similar data and a very careful identification. The ability of our analysis to estimate a dynamic transition of the outcome variables relates our research to the few existing studies that analyze the dynamic effects of immigration. Cohen-Goldner and Paserman

\footnotetext{
${ }^{5}$ This line of analysis is emphasized in Manacorda, Manning, and Wadsworth (2012); Ottaviano and Peri (2005, 2012); D'Amuri, Ottaviano, and Peri (2010).

${ }^{6}$ One paper analyzing this channel is Peri and Sparber (2009).

${ }^{7}$ Examples are Lewis (2011, 2013); Ottaviano, Peri, and Wright (2013).

${ }^{8}$ See also the recent analysis of immigration and productivity in Peri (2012), immigration and firm creation in Olney (2013) and immigration and economic growth in Ortega and Peri (2013).

${ }^{9}$ The difference-in-difference methodology is somewhat reminiscent of Von Wachter, Song, and Manchester (2007) who use a similar approach to track the long run effects of job separations in recession.
} 
(2011), for instance, allow for labor market effects of immigration on natives to change over time assuming that this is due to the dynamic adjustment of capital and not to a dynamic response of natives.

Our approach tackles also the criticisms moved by some recent studies to the so-called "area" approach in analyzing immigration. Borjas (2003) and other argue that wage effects of immigrants are not captured when limiting the analysis within a geographic area. By following individuals, our approach captures the effects of immigrants on individuals that may "spill" to other regions through mobility. Moreover by comparing municipality-based and individual-based dynamic responses over time we can establish directly whether spillovers have an important role in understanding the impact of immigrants.

The rest of the paper is organized as follows. Section 2 describes the dispersal policy and the characteristics of the refugee-county immigrants. Section 3 presents the data, their trends and summary statistics. Section 4 describes our two empirical approaches and the identification assumptions. Section 5 shows and discusses the empirical results and some extensions. Section 6 concludes the paper.

\section{Refugees in Denmark}

Immigrants (foreign-born) represented three percent or less of total employment in Denmark until 1994 and they were almost equally divided between those from the European Union (EU) ${ }^{10}$ and those from outside the European Union (non-EU) as shown in Figure 1. The figure shows that beginning in 1995 the presence of non-EU immigrants started to grow reaching a peak of $4.7 \%$ in 2008. Part of this significant growth of non-EU immigrants was driven by the inflow of immigrants from "refugee countries" that experienced significant conflicts between 1995 and 2003, especially Former Yugoslavia, Somalia, Afghanistan and Iraq. The inflow of immigrants from those countries grew in the 1990's and in the 2000's first in the form of refugees and then as families were re-unified with refugees. Let us describe in greater detail the events involving the inflows and distribution of these immigrants.

A well-organized and centralized program to admit and distribute refugees across 275 Danish municipalities was set in place in 1986 and it was administered by the Danish Refugee Council until 1998 (Damm, 2009). ${ }^{11}$ This program distributed

\footnotetext{
${ }^{10}$ We call EU immigrants those from the EU15 countries plus Norway, Iceland and Liechtenstein (European Economic Area) and Switzerland (bilateral agreement).

${ }^{11}$ In our analysis we use the new and larger municipalities as local labor markets. They are 97
} 
all the incoming refugees based only on information about their nationality and family size. The Refugee Council had no information on the skills, education, labor market abilities and Danish language proficiency of those individuals. The goals of the Refugee Council were two. First, it allocated refugees to obtain a balanced distribution across communities as a way to even out their housing burden. A key aspect of the dispersal policy, in fact, was the availability of temporary housing to refugee families and the provision of assistance in finding permanent housing. Access to temporary housing via this program ensured a very high take-up rate of the settlement offers: refugees accepted in more than $90 \%$ of the cases and they stayed in the municipality where they were assigned, on average for 18 months, although they were not forced to do so (see Damm, 2009, page 286). The second goal of the Refugee Council was to create ethnic clusters in the distribution of refugees, with the idea that individuals were more likely to help each other when living in enclaves of people of the same nationality. Hence, within the aggregate distribution of refugees across municipalities, national clusters emerged because of uneven distribution of nationalities. The location of national clusters was accidental, as it depended on the timing of specific inflows and on the availability of houses at that time. Local Danish communities (municipalities) had little say on which or how many refugees they could accept as the decisions of the Refugee Council were communicated to them once the temporary housing had already been arranged in the community.

Such a dispersal policy, therefore, generated national clusters of refugees that were independent of local labor market conditions between 1986 and 1994. Then, between 1995 and 2003 a sequence of large waves of immigrants from the regions of Former Yugoslavia and then from Somalia, Afghanistan and Iraq (refugee countries) entered Denmark, driven by major conflicts in their countries of origin. Figure 2 shows the cumulated number of immigrants from each of these four countries standardizing to zero their population in Denmark as of 1995. While we see a growth in immigrants from Somalia and Iraq already before 1995, we notice that 1995 ushers a period of sudden and large inflow of immigrants from these countries that lasted until 2003. Notice, as term of comparison, that immigration from Eastern Europe (reported as a solid line in Figure 2) did not pick up until the later accession of Romania and Bulgaria to the EU after 2005. Hence, the national clusters distributed accidentally by the dispersal policy became focal points for new immiafter merging Frederiksberg and Copenhagen. 
grants coming from conflict-torn areas. Beginning in the mid 1990's several family members re-unified with refugee-country immigrants and the dispersal policy was abandoned. Hence, the large inflows from the eight "refugee countries" produced differential variation in migrants across municipalities due to the spatial differences in nationalities generated by the dispersal policy.

Table 1 shows the effect of the initial refugee-country concentration across municipalities on the subsequent inflow of immigrants from refugee countries. We divide municipalities in quartiles according to the level of the eight refugee-country immigrants relative to population as distributed by the Dispersal Policy. ${ }^{12}$ The municipalities in the top quartile hosted a somewhat larger population of refugeecountry immigrants in $1994 .{ }^{13}$ However, their presence was limited and equal to 0.76 percent of employment in 1994. In municipalities at the bottom quartile only 0.23 percent of employment in 1994 was from refugee-country immigrants. This difference of 0.5 percentage points of employment was stable before 1994 but it grew more than threefold to a difference of 1.6 percentage points by 2008 because of the significant inflows from those countries. Table 1 shows also that such a differential growth in refugee-country immigrants is responsible for about half of the differential growth in non-EU immigrants as share of employment across the top and the bottom quartile of municipalities (that increased by 2.6 percentage points). To the contrary the differential in the presence of EU immigrants across those municipalities remained almost unchanged (increase by only 0.3 percentage points) during the period 1994-2008. This suggests that differential labor demand was not likely to be the reason for differential growth of refugee-country immigrants, as EU immigrants, free to locate where jobs were, would have responded to those.

Table 2 shows some important features of refugee-country immigrants, as a group, relative to natives. They were significantly less educated than natives and employed in elementary and often manual-intensive types of occupations. This feature is important as it informs what type of native workers would be more likely to compete with them. Forty percent of refugee-country immigrants (and likely more, if we consider most of those with unknown education as less educated) did not have a post-secondary education while for natives it was only 32 percent. Most

\footnotetext{
${ }^{12}$ Recall that the eight refugee countries are Yugoslavia, Somalia, Afghanistan, Iraq, Sri Lanka, Vietnam, Iran and Lebanon as they generated a substantial inflow of refugees during the period 1994-2008.

${ }^{13}$ Notice, that the actual stock (differently from the new inflow each year of the policy) include relocated immigrants.
} 
of the individuals from refugee countries did not speak Danish and they were culturally and ethnically different from natives. They were more likely than natives to be employed in manual occupations and less likely than natives to be in the more complex, cognitive-intensive and highly paid occupations. Table 2 shows also that the least complex type of occupations ("sale and elementary service occupations" ) employed $13 \%$ of refugee-country immigrants while only $4 \%$ of natives. At the other end of the spectrum the most complex type of occupations ("legislator and senior officials") did not employ any refugee-country immigrant.

Table 3 shows more evidence of the concentration of refugee-country immigrants in occupations with high manual and low cognitive and communication content. The table shows the five occupations with the smallest (Panel A) and the largest (Panel B) net inflow of refugee-country immigrants in the period 1994-2008, measured as change in their share of employment. We see that the low-inflow occupations are very high in cognitive and communication content (as we will define more precisely below) and they are low in manual task content, while vice-versa the large-inflow occupations are high in manual content and low in cognitive-communication content. Immigration from refugee-sending countries, therefore, represented an increase in the supply of labor in manual-intensive, elementary types of occupations. Those were overwhelmingly performed by natives with no post-secondary education, and hence this is the group of workers whose response to refugee-country immigrants we will analyze more closely as they may be the most negatively affected by competition. High skilled natives, to the contrary, are likely to be complementary to these type of workers, and we will also analyze refugee-country immigrants' impact on their labor market outcomes as comparison.

Figure 3 shows the dynamics of the average complexity index for high and low skilled native workers and for refugee-country immigrants aggregating over Denmark. Panel A includes only people who were working as of 1995 (hence only one cohort) while panel B includes all workers between 1995 and 2008. The figure clearly shows that refugee-country immigrants exhibit a much lower level of occupational complexity, and also that the level did not change much over time for a cohort or including new entrants between 1995 and 2008. Less skilled natives had a complexity level that increased markedly over time while high skilled natives had high average complexity that did not change as much over time. Hence, the aggregate time behavior is consistent with the idea that refugee-country immigrants increased permanently the supply of non-complex tasks in the labor market and less skilled 
natives responded by moving towards more complex tasks.

Let us conclude this section with few important observations about the Danish labor markets. Danish jobs exhibited high turnover rates, low costs of hiring and layoffs and decentralization in wage setting during the considered period (Dahl, le Maire, and Munch, 2013). In this flexible framework wage responses best reflect marginal productivity. The findings from this case are informative of the potential effect of unskilled immigrants on similar labor markets represented by the US or UK, rather than other continental European countries, because of their higher level of flexibility. Occupational and cross-firm mobility turn out to be important margins of adjustment in Denmark and this may help explain the positive correlation between immigration and employment/wage of natives that is also observed in the US (Card, 2009) and the UK (Dustmann, Frattini, and Preston, 2013).

\section{Data and Descriptive Statistics}

\subsection{Sample and Variables}

The core of our data is the Danish Integrated Database for Labor Market Research (IDA), a collection of administrative registers that link data on individual characteristics of the workers and data on the characteristics of establishments. The data are recorded annually, during the last week of November, for each individual in Denmark and include detailed information on occupation, salary, hours worked, individual demographics, and other workers' characteristics. They also include the industry, location and other basic characteristics of the establishment where the person is employed.

We select individuals who were between 18 and 65 years old, who were not attending school and not permanently disabled. ${ }^{14}$ We refer to this group as the "working-age population". We restrict our analysis of outcomes to a panel of Danishborn individuals. Those without college education, low skilled, are the workers in more direct competition with refugee-country immigrants and we focus our attention on their outcomes. For completeness and comparison we will also show the estimated effect of refugee-country immigrants on college educated (high skilled) natives.

The panel regression analysis (described in section 4.1) includes all individuals that are employed in November of each year. When turning to the difference-in-

\footnotetext{
${ }^{14}$ Bratsberg, Raaum, and Røed (2010) show that large fraction of non-EU immigrants in Norway take up disability pension. We do not include those immigrants in our analysis.
} 
difference analysis (described in section 4.2) we consider instead a balanced panel of individuals and we follow them without imposing further restrictions as they transit into and out of employment and across jobs. In this second sample we select natives aged 21 - 51 in year 1994 who therefore satisfy the age criterion for being in working-age population $(18-65)$ throughout our analysis. An individual will be in the sample continuously unless he/she becomes disabled, leaves Denmark or dies within the 1991-2008 period. In the analysis of the effect of immigration on the employment margin we distinguish two subgroups in the balanced panel: those employed as of November 1994 and those not employed in November 1994.

In all specifications of the empirical analysis we consider three main outcome variables. The first is a measure of the complexity of tasks performed by a native worker on the job. This index is obtained using information on the task intensity of each occupation from the O*NET database (US Bureau of Labor Statistics) along the dimensions of manual, communication and cognitive content and aggregating them. The complexity index follows Ottaviano, Peri, and Wright (2013) and is increasing in communication and cognitive content while it is decreasing in manual content. We provide details about the underlying task data and the link to Danish registers in the Online Appendix. We also show results using each component of the index (Manual, Cognitive and Manual). The second outcome is the (logarithm of) hourly wage of a native worker, calculated including mandatory payments to pension schemes and deflated using the Danish consumer price index. ${ }^{15}$ The third is a measure of individual labor supply captured by the fraction of a year worked. This variable equals one if the worker was a full-time employee throughout the year. If either the person was part-time employed and/or if the person was only employed part of the year, the employment variable takes a fractional value equal to the share of the regular working year which was spent at work. The employment variable is measured for each Danish native individual while the occupational index and the hourly wage measure are available only for those individuals who were employed at the end of November.

We also construct a variable that we call "occupational mobility" that equals one whenever an individual changes occupation between year $t-1$ and $t$. So our data, by following people over time, allow us to study occupational mobility of individuals.

\footnotetext{
${ }^{15}$ The mandatory pension contributions vary across industries. As data on the pension payments are available only from 1995 onwards, we consider wage net of pension contributions when we include pre-1995 data. The fixed effect analysis that can be implemented with net or gross earnings proved to be robust to the choice of income measures.
} 
The effect on the complexity index captures the direction of such mobility in the complexity space. Namely, if a worker changes job and moves to an occupation with higher complexity we consider such a move as a transition to more complex tasks, usually associated with higher pay and lower unemployment risk.

The individual level characteristics that we use as controls are age, labor market experience (cumulative employment in years since first joining the labor force), tenure in the current job (calculated as the period elapsed between the hiring in the current establishment and the current period), level of education, marital status, region and industry of employment. Summary statistics of the controls and of the dependent variables used in the empirical analysis are provided in Table $4 .^{16}$ The table shows summary statistics for the sample of native workers used in the fixed effect regressions. ${ }^{17}$

\subsection{Local Labor Markets}

The geographic units of analysis, that we use to approximate local labor markets, are the municipalities that can be identified consistently in Denmark, beginning in 1988 up to 2008. We merge Frederiksberg and Copenhagen since those two municipalities constitute one integrated labor market. This leaves us with 97 areas where Copenhagen, Aarhus and Aalborg are the biggest and most populous ones. ${ }^{18}$ While these geographical units are rather small we can follow workers across municipalities and hence we do not have to make any assumptions about them being closed economies. We are simply assuming that immigration in the municipality of work is a good proxy of the intensity of exposure of a native worker to the competition and to the opportunity brought by those immigrants. Most of the mobility of workers takes place across firms within municipality confirming that municipalities are, even in the long run, rather self-contained labor markets. Only around 10 percent of the

\footnotetext{
${ }^{16}$ The empirical analysis is based on a 20 percent random sample of native individuals. Immigrant shares (the explanatory variable of interest and the instrument) are calculated on the full sample to avoid measurement error.

${ }^{17}$ The balanced panel used in the difference-in-difference analysis has similar summary statsitics in terms of age, labor market experience, education and wages to those reported in Table 4.

${ }^{18}$ Copenhagen (including Frederiksberg) had 603 thousand inhabitants in 2008, and Aarhus and Aalborg had, respectively, 298 and 195 thousand inhabitants. The smallest municipalities are islands with two to seven thousands inhabitants, which will count very little in our estimations. The next smallest municipalities begin at around twelve thousand. In the large cities the employment/population ratio is about 60 percent, while it is 40 percent in the more isolated, rural municipalities.
} 
workers who move across establishments each year change municipality. ${ }^{19}$

\section{Empirical Approach and Identification}

\subsection{Individual Workers: Fixed Effects Panel Regressions}

The first empirical approach that we implement estimates panel regressions with large number of fixed effects using 2SLS methods. By including different sets of fixed effects, we identify the response of native low skilled workers either within their establishment spells, or within their municipality spells or including their whole working experience 1995-2008.

We indicate the outcomes of native $(N A T)$ individual $i$ in establishment $j$ in municipality $m$ at time $t$ as the variable $y_{i j m t}^{N A T}$ in regression (1) below. We analyze occupational complexity, task intensity, occupational mobility, the logarithm of hourly wages and employment, measured as fraction of working year, as outcome variables. The main explanatory variable is the refugee-country immigrant share of employment in municipality $m$ and year $t, S_{m t}$, calculated as $F_{m t} / P_{m t}$ where $F_{m t}$ is the stock of employed immigrants from refugee-countries and $P_{m t}$ is the total employment in municipality $m$ and year $t$. The regressions that we estimate have the following structure:

$$
y_{i j m t}^{N A T}=x_{i t}^{\prime} \alpha+\beta S_{m t}+\phi_{t, I N D}+\phi_{t, R E G}+\gamma_{i, u}+\varepsilon_{i j m t}
$$

The variable $x_{i t}$ is a vector of time-varying individual characteristics which include age, age squared, labor market experience, experience squared, tenure on the job, tenure squared, education, and whether the person is married. The variables $\phi_{t, I N D}$ and $\phi_{t, R E G}$ are industry-by-year and region-by-year effects capturing regional and industry-specific time patterns. Regions are the five administrative regions in Denmark and industries are the eight industries of the 1-digit NACE industrial classification scheme. ${ }^{20}$

In our 2SLS estimation analysis we instrument the explanatory variable $S_{m t}$ with $\widehat{S}_{m t}$ that uses the refugee dispersal policy and is described in section 4.3. The

\footnotetext{
${ }^{19}$ As Copenhagen is a metropolitan area significantly larger than the others and it attracts a large part of non-refugee immigrants we have also performed the regression analysis in section 5.1 excluding it. The results are very similar to those obtained including Copenhagen and we did not report them. They are available upon request.

${ }^{20}$ The regions and the industries are listed in Table 4.
} 
variables indicated by $\gamma_{i, u}$ represent fixed effects for each individual $i$ and unit $u$ combination. Depending on which unit $u$ we choose, the inclusion of these effects allow us to identify the impact of immigration on outcomes within that unit. In the first set of regressions we choose the unit $u$ to be an establishment, $j$, so that the set of fixed effects $\gamma_{i, j}$ will vary for each employee-establishment pair. ${ }^{21}$ Such regression identifies the impact of an increased supply of refugee-country immigrants on the outcome of native workers within an establishment. While such an extensive set of fixed effects allows us to absorb any heterogeneity in employee-establishment matches, reducing drastically the scope for omitted variable bias, it may also miss important effects that are systematically different when workers change establishment.

For this reason the second group of regressions include a set of individualmunicipality fixed effects $\gamma_{i, m}$ instead. This specification estimates the impact of immigrants on outcomes of native workers within their municipality spells but across establishments. Differences with the previous specification reveal that some effects might be more or less pronounced when leveraging workers' experience across establishments. This help understand, for instance, whether the specialization adjustment of natives takes place prevalently within or across establishments.

Finally, the third version of equation (1) includes individual fixed effects (with no $u$ interaction) so as to capture the response to immigrants within the whole individual workers's experience. This is a more classic panel fixed effect estimation based only on within-individual variation. If immigration affects natives when they move out of the municipality in a systematically different way than while they stay, this method will provide estimates different from the previous two. To account for the correlation of errors across individuals and years within municipality we cluster standard errors at the municipality level (for individual fixed effects straddling over several municipalities the level of the cluster is the initial municipality).

The three panel regressions described produce an informative picture of the effects of refugee-country immigrants on native outcomes. Together they range from very tightly identified, but possibly narrower effects within a worker-establishment spell, to broader but possibly less cleanly identified effects, over individual working experiences. However, as they are considering only the contemporaneous effects of immigration on working natives, they can hardly be used to obtain an estimate of

\footnotetext{
${ }^{21}$ This is similar to the fixed effects used in Hummels et al. (2014) and Malchow-Møller, Munch, and Skaksen (2011).
} 
the dynamic, short and long run effects of immigration and of the effect on the employment/non-employment margin. These shortcomings are addressed by the specification described next (section 4.2).

\subsection{Following People or Municipalities: Difference-in-Difference}

Our second approach uses a difference-in-difference design to identify the short and long run effect of immigrants on less educated native workers who resided in a Danish municipality in 1994. We follow their outcomes, including those who moved out of the municipality or out of employment. We choose 1995 as beginning of the treatment period as figures 1 and 2 show a discontinuous increase in refugeecountry immigration beginning in that year. We discretize immigration exposure across municipalities using differences in refugee-country immigrants determined by the dispersal policy. The exact construction is explained in section 4.3. We define as "exposed to immigration" or "treated" those municipalities in the top quartile of the refugee-country immigration exposure ranking, and as "non-exposed" or "control" those in the bottom quartile. ${ }^{22}$ In order to leverage such a difference we only include individuals in the top and bottom quartile municipalities in the difference-in-difference regressions.

This set-up allows us to define a pre-treatment period represented by the years 1991-1994 during which refugee-country immigrants in Denmark were not abundant. Then, we consider a treatment period going from 1995 to 2008 during which the number of refugee-country immigrants surged. The ethnic enclaves of refugeecountry immigrants, generated during the dispersal policy, were joined by many more immigrants due to prolonged crises in the source countries. We then compare the labor market outcomes of low skilled natives during the treatment period in high exposure municipalities relative to low exposure to identify the effect. We can also test the pre-1995 trend in native outcomes between exposed and non-exposed municipalities to see whether the performance of native low skilled workers differed already before the treatment period of large refugee-country immigration.

We implement the difference-in-difference estimation in a regression setting. The variable $y_{i m t}^{N A T}$ represents an outcome for native individual $i$ in municipality $m$ in year $t$ as in equation (1). The outcomes are occupational complexity, manual intensity, hourly wages and employment as fraction of year worked. The explanatory

\footnotetext{
${ }^{22}$ Specifically, the population weighted distribution of the 1994-2008 difference in the predicted refugeee-country immigrant share is our measure of immigration exposure.
} 
variable of interest is the treatment dummy $M_{i m t}$ equal to one if individual $i$ is in an exposed municipality and 0 if the individual is in a non-exposed one. This variable is interacted with a set of year dummies, $D($ year $=t)$, equal to 1 in year $t$ and zero otherwise. The year variable is defined so that 1994 is year 0 and 1 to 14 corresponds to the treatment period, while -3 to 0 is the pre-treatment period. ${ }^{23}$

The variable $x_{i t}^{\prime}$ represents the same individual controls as included in (1) and the variables $\phi_{m}$ are fixed effects for each municipality. The detailed year effects are industry-by-year $\left(\phi_{t, I N D}\right)$, region-by-year $\left(\phi_{t, R E G}\right)$, education-by-year $\left(\phi_{t, E D U C}\right)$, and occupation-by-year $\left(\phi_{t, O C C}\right){ }^{24}$ The equation that we estimate is:

$$
\begin{aligned}
y_{i m t}^{N A T}= & x_{i t}^{\prime} \alpha+\sum_{t=-3}^{-1} \gamma_{t} M_{i m t} D(\text { year }=t)+\sum_{t=1}^{14} \gamma_{t} M_{i m t} D(\text { year }=t)+ \\
& +\phi_{t, I N D}+\phi_{t, R E G}+\phi_{t, E D U C}+\phi_{t, O C C}+\phi_{m t}+\varepsilon_{i t}
\end{aligned}
$$

The coefficients $\gamma_{t}$ capture the difference in individual outcomes from 1991 (year -3) to 2008 (year 14) between individuals in treated and non-treated municipalities, standardized to zero in year 0 which is 1994 . We will show these coefficients in the panels of section 5 .

Within the common framework of expression (2) we specify two different regressions. One is designed to follow individual workers who were in a treated or a control municipalities as of 1994. This specification implies that we define the treatment, the controls and the fixed effects based on the location/characteristics of worker $i$ in 1994 and we characterize this specification as following the cohort of individuals. The indicator $M_{i m t}$ is one in this specification if individual $i$ was in a treated municipality $m$ in 1994 no matter where he/she is in year $t$. Hence, the indicator variable does not vary with $t$. Similarly all covariates included as controls are fixed for the worker in 1994.

The other regression tracks the evolution of outcomes in municipalities instead. In this case the indicator $M_{i m t}$ is one if individual $i$ is in a treated municipality $m$ in year $t$. Hence, individuals included in the "treated" group may change over time, as they move in or out of treated municipalities. The control and fixed effects are

\footnotetext{
${ }^{23}$ As we include municipality and year effects in the model we omit year 0 in the interactions with the treatment dummy. Hence, 1994 is the reference year.

${ }^{24}$ The occupation categories are unskilled worker (reference), skilled worker, intermediate professional, higher grade professional and manager. The education categories, the regions and the industries are the same as in equation (1).
} 
also relative to the individual in year $t$. This approach mirrors, in an individuallevel setting, the repeated cross-section regressions often seen in the literature that estimate the effect for the average worker in the municipality. The effect obtained this way will combine the impact of immigration on individuals who remain in the municipality and the contribution of natives who (selectively) join and it will miss the contribution of those who (selectively) leave. Hence, this second approach is not as clean in terms of exogeneity of the explanatory variable as the first, but it mirrors the typical area approach of the existing literature. The comparison of the two approaches will tell us whether we miss some important features of the impact of immigration on native outcomes when we follow the local labor market (municipality) effect rather than the average individual effect. Standard errors are clustered at the municipality level.

\subsubsection{Cumulated Long Differences}

Finally, we want to capture the effect of immigration on the cumulated individual outcomes for the whole 1995-2008 period, in a framework similar to equation (2). To do that we calculate as outcome the cumulative time (in years) spent in the initial establishment or in establishments different from the first, the time spent in the initial municipality or in different municipalities, and in employment or in non-employment. We also calculate the cumulative effect on the present discounted value of earnings to summarize the overall impact on the exposed workers from 1995 to 2008. The regression on these cumulated variables is as follows:

$$
\Delta y_{i, m, 1995-2008}^{N A T}=\alpha x_{i, 1994}^{\prime}+\beta \Delta S_{m, 1994-2008}+\phi_{I N D}+\phi_{R E G}+\phi_{E D U C}+\phi_{O C C}+\varepsilon_{i}
$$

$\Delta y_{i, m, 1995-2008}^{N A T}$ in expression (3) represents the cumulated outcome from 1995 to 2008 for less-skilled natives, and $\Delta S_{m, 1994-2008}$ is the total change in the refugeecountry immigrant share of employment in region $m$ from 1994 (before the surge) to 2008. We instrument $\Delta S_{m, 1994-2008}$ with the change in the imputed refugee-country immigrant share of population based on the dispersal policy described in section 4.3. Equation (3) establishes whether refugee-country immigrants exposure has affected the propensity of less educated natives to change establishment or labor market, or to exit employment. By cumulating the effect and following individuals wherever they go this specification summarizes the long run effects of exposure to immigration in the initial location on individual mobility. Standard errors are clustered at the 
1994-municipality level, the level of variation in the variable of interest.

\subsection{Identification and Instrumental Variable}

The explanatory variable of interest measures refugee-country immigrant supply as their share of employment in municipality $m$ at time $t$. In the light of the dispersal policy and of the refugee-country immigrants inflows we build an instrument based on the distribution of new refugee-country immigrants during the dispersal period (1986-1998) but also leveraging the large flows from 1995 to 2008 where an increasing number of immigrants arrived via family reunification.

Let $F_{c t}$ denote the total working-age population of immigrants from refugeecountry c (Bosnia, Afghanistan, Somalia, Iraq, Iran, Vietnam, Sri Lanka and Lebanon) residing in Denmark in year $t$. Let $s_{\mathrm{cm}}$ indicate the share of new immigrants from country $c$ that settled, as first location, in municipality $m$ between 1986 and $1998 .{ }^{25}$ During this period of full application of the dispersal policy all individuals from refugee-countries were assigned according to it. Because of adherence to the policy the shares were independent of labor market conditions across municipalities. Then, after 1994 the aggregate flow from refugee countries increased and, progressively, they were not any longer assigned according to the dispersal policy which was phased out and many refugee-country immigrants came with family reunification permits. Hence for $t>1994$ we construct $\widehat{F}_{c m t}$ the imputed working-age population from refugee-sending country $c$ in municipality $m$ in year $t$ as follows: $\widehat{F}_{c m t}=s_{c m} \times F_{c t}$. This imputed population is constructed as a function of the shares $s_{c m}$ which were completely determined by the dispersal policies, and the total immigrant population from each country $c$ after 1994 which was in large part driven by refugee-country crises. We then aggregate across the refugee-countries and we obtain the total refugee-country working-age population. ${ }^{26}$ We standardize it by the total working-age population in municipality $m$ in year $1988, P_{m 1988}$. So the imputed refugee-country immigrant share is: $\widehat{S}_{m t}=\left(\sum_{c \in \text { Refugee }} \widehat{F}_{c m t}\right) / P_{m 1988}$. The variation of $\widehat{S}_{m t}$, over the years, after 1994, is only driven by the changes in the imputed refugee-country population distributed according to dispersal policy shares $s_{c m}$. This variable is used as instrument for the employment share of refugee-country

\footnotetext{
${ }^{25}$ This implies that $\sum_{m} s_{c m}=1$

${ }^{26}$ Bosnia is included in the measure of actual inflow but not in the instrument because a special Bosnia Programme might have reduced the randomness of location of those refugees.
} 
immigrants in municipality $m$ at time $t, S_{m t}$ in the panel regressions. ${ }^{27}$ It is also used to identify the top and the bottom quartile municipalities in their exposure to refugee-country immigrants in the difference-in-difference approach.

Let us emphasize that, although we have firm-level data on immigrants, our strategy uses the variation of immigrant supply across local labor markets (and not firms) to identify their impact. Doing this we can exploit the exogeneity of the dispersal policy that produced variation across municipalities, as described above. To the contrary, the hiring of immigrants across firms even before 1994 was certainly affected by firm-specific factors. If those factors were persistent they might be correlated with native labor market outcomes in the period of analysis. ${ }^{28}$

The power of this instrument depends on how strong was the tendency of post1994 immigrants from refugee countries to cluster in the enclaves generated by the dispersal policy, and we will test this in the first stage. The exclusion restriction for the validity of the instruments requires that the imputed inflows of refugee-country immigrants in municipalities are uncorrelated with the unobserved determinants of municipal labor demand after 1995 once we control for fixed effects and observed variables. The plausibility of the exclusion restriction is predicated on the independence of the dispersal policy from labor demand conditions. We perform, however, some important tests of this restriction. Specifically, in Table 5 we analyze whether the 1994-2008 change in the instrument $\widehat{S}_{m t}$ is correlated across municipalities with trends in the outcome variables (occupational complexity, hourly wages and fraction of year worked) for low skilled natives in the pre-1994 (pre-treatment) period. The unit of observation in these regressions are the municipalities. A significant correlation with trends that pre-date the refugee-country immigrant surge would cast doubts on the validity of the instrument as it would reveal some persistent trend affecting outcomes and correlated with the instrument.

The regressions of Table 5 include age, labor market experience, job tenure, (and each of them squared) and marital status averaged over the labor force in each municipality in 1994 as controls. The regressions weight each municipality by its labor force as of 1994. The first row shows the correlation of the (change in the)

\footnotetext{
${ }^{27}$ Notice that while the explanatory variable $S_{m t}$ is constructed using employment data, the instrument $\widehat{S}_{m t}$ is built using working-age population. This add a further degree of exogeneity to the instrument.

${ }^{28}$ Recently, Dustmann and Glitz (2011) also considered the immigrants'presence in local labor markets, rather than in firms, when analyzing the adjustment mechanisms through which local firms absorb them.
} 
instrument $\widehat{S}_{m t}$ with the outcomes (in 1991-1994 differences) for low skilled. The estimated coefficients on the pre-1994 changes are small and far from statistical significance at any standard level. Reassuringly they imply that there was no correlation between the pre-1994 trends in outcomes and the successive imputed inflow of refugee-country immigrant across municipalities.

The fourth column of table 5 shows another interesting fact, namely that there is no correlation between the prediction of the instrument and the actual immigration from EU countries. As EU immigrants were free to locate where they choose in Denmark, and most of them migrated for working reasons, we can infer that the distribution of imputed refugee-country immigrants being orthogonal to that of EU immigrants suggests very low correlation of the first with local labor demand shifts in the 1995-2008 period. Finally, column 5 of Table 5 shows the power of the instrument. The correlation of the change in the instrument with the actual change in the refugee-country immigrant share of employment exhibits a very significant coefficient and large $F$-statistic (close to 49 ). These tests together suggest that the instrument is strong and valid as the correlation with pre-1994 economic outcomes and with economically motivated migrants (the EU immigrants) are low, while the correlation with the explanatory variable is high. A concern for identification can also be the attenuation bias produced by measurement error. In this type of regressions, Aydemir and Borjas (2011) pointed out that the share of immigrants can be measured with significant error in surveys leading to important bias. Our data, however, are not subject to measurement error arising from sampling as we calculate the immigrant shares of each municipality based on the full population registers (and not on a sample) thereby eliminating these concerns.

\section{$5 \quad$ Results}

\subsection{Effects on Individual Workers}

Table 6 shows the panel estimates of the effect of immigrants on low skilled natives. The table shows only the estimates of the coefficient of interest, namely $\beta$ in equation (1) which captures the effect on the outcome variable of an increase in refugeecountry immigrants by 1 percentage point of employment. Each entry in the table is an estimate from a different regression using different outcomes listed as entries in the corresponding row. Columns 1, 3 and 5 show the OLS estimates, while columns 
2,4 , and 6 show the 2SLS estimates of the coefficient of interest for three different sets of fixed effects. The first two columns show the results when controlling for the individual-establishment fixed effects; hence, they identify the effect of immigrants on native workers within establishment spells. Columns 3 and 4 show the results when including the individual-municipality fixed effects and capture the effect of immigration on a native workers within municipality spells. Finally, columns 5 and 6 show results when only including individual fixed effects and hence capture the impact on native workers including all working spells.

In the first row of Table 6 we show the effects of an increase in immigrants on the occupational complexity of low skilled native workers. The second, third and fourth rows report the estimated effects on the underlying skill intensities (manual, communication and cognitive) used to construct the complexity index. As the task intensity of jobs is inferred from occupations and changes in that intensity reveal move across occupations in the fifth row we report, for completeness, the effects of immigrants on unskilled native occupational mobility. Occupational mobility is measured as a dummy that equals one if an individual changed (4-digit ISCO-88) occupation from one year to the following. The sixth row shows the effects on (the logarithm of) hourly wages, and the seventh row shows the effect on individual time worked measured as fraction of the working year. The number of observations in the regression is shown next and the $F$-statistic and the coefficient on the excluded instrument in the first stage regression appear in the last two rows of the table. In parenthesis under each estimated coefficient, we report the heteroskedasticity robust standard errors clustered at the municipality level to account for correlation of errors within-municipality.

A tendency of immigrants to settle in areas with fast growing labor demand would usually generate an upward bias in the OLS estimates of the effect on native wages and employment. However, we are considering a special group of immigrants whose population, as shown above, grew from initial settlements of refugees whose location was centrally decided and uncorrelated with initial economic conditions and then grew because of co-location of families and groups rather than responding to labor demand. Hence, the OLS estimates might not be upward biased in this case. The IV regression, however, should isolate more cleanly the immigration due to dispersal and refugee-country crises. The differences between the OLS and IV, in Table 6, are rarely significant and usually they reveal a downward bias of OLS estimates which may suggest a negative correlation between the actual inflow of these 
immigrants and the contemporaneous labor market conditions for unskilled natives. Refugee-country immigrants did not seem to settle in booming municipalities. The instrument is usually fairly strong with an $F$-statistics of the first stage always above 50. A value of 10 or higher is considered as sufficient to avoid issues of significant weak instrument bias (Stock and Yogo, 2005).

Several interesting results emerge from Table 6 which are all consistent with a response of less skilled native workers to the immigrants in the direction of taking advantage of complementarity and opportunities generated by this group of workers. ${ }^{29}$ Focussing on the IV estimates, we see that unskilled native workers experienced a significant transition towards more complex jobs. Two new and interesting features of this transition are revealed. On one hand, the more significant transition is to jobs with lower manual task content, in line with the idea that refugee-country immigrants concentrate in those type of jobs and pushed natives away from them. On the other hand, the occupational transition is significant only when considering workers across establishments and municipality. For spells within an establishment there is not much skill/task adjustment.

The estimates of columns 4 and 6, that include workers' spells across establishments and municipalities, imply that an increase in refugee-country immigrants by 1 percentage point of employment increases the complexity of native jobs between 1.3 and $3.1 \%$. This is novel to the literature as previous studies could not identify whether occupational transitions and specialization took place within or across firms. The current results suggest that the specialization response of native unskilled takes place mainly with transitions across establishments. The second interesting result is that within establishment, across establishments and across municipalities, native workers' hourly wages are affected positively by the refugee-country immigrants. The estimated effects are positive and usually significant (if not very precise) and imply a 1 to $1.8 \%$ native wage increase for each immigrant inflow equal to 1 percentage point of employment. Interestingly, the wage effect is not very different across the three different panel regressions. A plausible interpretation is that native unskilled workers who remain within an establishment after new immigrants come in are those performing the more complementary tasks (less manual and more cognitive). Hence, they benefit from their complementarity within firm and this shows in higher wages and labor supply. Those leaving establishments, instead, are the

\footnotetext{
${ }^{29}$ This is similar to what found in Peri and Sparber (2009) and D'Amuri and Peri (2014) but the present analysis reveals much richer details and a clearer picture of the dynamics of this process.
} 
ones doing more manual-intensive jobs, but they leave the establishment to transition into non-manual jobs, so that in the end this upgrade allows their wages to increase too. The final interesting result from Table 6 is that for all native workers the labor supply increases slightly or remains unchanged in response to immigrants, confirming an effect consistent with complementarity in production. ${ }^{30}$

Quantitatively the estimated effects are not unreasonably large. As stated above a one percentage points increase in the share of low skilled immigrants from refugeesending countries increased wages for low skilled native workers by 1 to 1.8 percent. The overall increase in average real wages in Denmark during the 1994-2008 period was 18 percentage points for less skilled workers, hence immigration of refugeecountry immigrants contributed, but only very little, to the good wage performance of Danish low skilled in this period. As a comparison, the estimated effect of total immigration 1990-2006 on unskilled US workers (no high school degree) calculated using the preferred specifications of Ottaviano and Peri (2012, Table 6, columns 6-9) range between 0.6 and 1.7 percent, and are therefore not very different from these.

\subsection{Interpreting the Estimates}

The panel regressions suggest that refugee-country immigrants, who specialized mainly in manual, low skilled jobs, encouraged low skilled natives to take more complex occupations, decreasing the manual content of their jobs especially when changing establishment and this contributed to produce a positive effect on their wages and employment. In no specification we find crowding out of native unskilled workers (i.e. negative effects on employment) or depressing effects on their wages. These results can be interpreted in a simple skill-specialization framework of the type suggested by Peri and Sparber (2009) and used in Docquier, Ozden, and Peri (2014) and similar to Card (2009). Low skilled natives and immigrants are imperfect substitutes and this is because they perform different tasks. Moreover low skilled immigrants and high skilled natives are complements as they perform very different

\footnotetext{
${ }^{30}$ We are unable with our data to establish whether immigrants had an impact on local prices as there is no information on those. We can emphasize, however, that most of the literature on the effect of immigrants on house prices (the largest component of local prices) finds that highly skilled immigrants (richer and more frequently home owners) had a significant impact (e.g. Peri, Sparber, and Shih, forthcoming). Moreover in this case, we consider only refugee-country immigrants, the majority of whom was given public housing, making it unlikely that they had a large effect on the price of private housing.
} 
tasks. ${ }^{31}$ This would explain a potentially positive effect of immigrants on native unskilled wages and a positive larger effect on native skilled.

The results in section 5.1 show that low skilled immigration itself pushes natives to become more complementary to immigrants through changing specialization, especially across establishments. Moving to complementary jobs and specializing in non-manual tasks are key mechanisms in obtaining the positive results on low skilled wages. The simple theoretical model implies also that low skilled immigrants are complement of high skilled natives and for that group, already engaged in complex production tasks, there should be less (or no) effect on specialization but still positive wage effect. To check this, we report in Table 7 the estimated effects on the outcomes for high skilled natives. This table has the exact same structure as Table 6 . The table shows that in this case the effects on complexity and manual tasks are much smaller (the point estimates are one half to one third of those for less skilled) especially considering spells that include establishment and municipality change (columns 4 and 6). The effects on wages, however, are significant and larger for high skilled than for less skilled (at least considering workers within municipalities). These effects are consistent with the above interpretation of complementarity in the productive skills of refugee-country immigrants and high skilled natives. As high skilled are likely to perform cognitive and complex tasks, they have no need to change specialization and they benefit from a positive complementarity effect from workers who fill manual-type of jobs.

From the estimates of the wage effect of refugee-country immigrants in Table 6 and Table 7 we can also identify the implicit elasticity of substitution between high and low skilled natives. This is given by the inverse of the high-low skilled difference in logarithmic wage changes in response to an increase in relative low skill supply by one percentage point, driven by refugee-country immigrants. Hence, taking the average estimates from the statistically significant wage effects of Table 6 and 7 , we obtain a differential logarithmic impact of $0.5(2.2-1.7)$ which implies an elasticity of substitution equal to 2 between the high and low skilled. This is very close to the one used in the literature (e.g. by Ottaviano and Peri, 2012, who choose a value of 1.75). Refugee-country immigrants, being imperfect substitutes of natives because of their specialization, had a positive impact on wages of both skill groups of natives.

\footnotetext{
${ }^{31}$ In the theoretical models as summarized in Lewis and Peri (2015) high and less skilled are considered as two different labor inputs and they are combined in a CES production function. Manual and non-manual tasks, within the less skilled group, are considered also as two inputs and combined in a CES function nested in the previous one.
} 
However, they also increased the wage differential between them as they were more complementary to high than to low skilled.

\subsection{Effects on Cohorts and Areas}

The panels in Figure 4 show the estimated coefficients $\gamma_{t}$ (solid line) and their $95 \%$ confidence interval (dashed lines) from equation (2) for each year, with 1994 (0) as the reference year. ${ }^{32}$ These coefficients show the difference in native less skilled workers' outcomes between municipalities exposed to refugee-country immigrants (treated) relative to less exposed municipalities (control). The panels from top to bottom represent four different outcomes: Occupation complexity (panels A and B), manual intensity (panels $\mathrm{C}$ and $\mathrm{D}$ ), hourly wage (panels $\mathrm{E}$ and $\mathrm{F}$ ) and fraction of year worked (panels $\mathrm{G}$ and $\mathrm{H}$ ). The left-right sets of figures represent estimates from the specification that follows individual cohorts (left column) or the specification that follows municipalities (right column). These pictures allow us to see how the adjustments and effects of immigrants on natives unfolded over time. We see how long it takes for the full impact to occur since year 0 , the beginning of the large refugee-country immigrant flow. We can also detect if the effect is temporary or permanent. A second important feature of the pictures is that the trajectories allow us to check whether there was a trend differentiating the treated and control regions already before the large inflow started (between year -3 and 0). Finally, by comparing the cohort and the area transitions we can see whether individual mobility systematically attenuate the area effects.

Some results emerge clearly from the difference-in-difference approach, and they are consistent with those from the panel approach and enrich our understanding of the native response to immigrants. First, the cohort of native unskilled individuals from highly exposed municipalities has a clear gradual and permanent shift towards more complex and less manual tasks. The shift is significant (about $4 \%$ increase in the complexity index in the exposed municipalities) and it took place gradually in the years between one and nine, corresponding to the period 1995-2003 where the refugee-country immigrant populations grew (Figure 2). The effects is still significant after 15 years (in 2008) suggesting a permanent shift.

Comparing the effects following the cohort of individuals (left panels) to those following the municipality (right panels) we notice a small (not statistically signifi-

\footnotetext{
${ }^{32}$ For completeness Table A.1 in Online Appendix reports the estimates and standard errors for selected years, and Figure A.1 shows the corresponding graphs for high skilled natives.
} 
cant) difference, with the second response somewhat attenuated relative to the first. This is true also for the wage and employment effects, which may indicate that some of the effects on native workers spilled to other municipalities. However, the magnitude and direction of the effects are consistent and similar between cohort and municipality suggesting that, differently to what argued in some previous research (e.g. Borjas (2008) and Borjas (2014) chapter 6), the area analysis is quite informative of the overall direction and magnitude of the effects of immigrants on native labor market outcomes. Panel $\mathrm{E}$ and $\mathrm{F}$ show the positive wage effect on native unskilled which follows a gradual trajectory, mirroring the change in specialization. Especially, when following the individual cohort (panel E), we observe a positive effect on wages that is still significant after 15 years. Wages of native unskilled exhibit a permanent increase by $2.4 \%$ in more exposed municipalities when we follow the individual cohort. The average wage effect when following the municipality is closer to $1.4 \%$. Both effects are significant in almost each year after year 3. Finally the effect on labor supply is mostly insignificant and it is negative in the case of the cohort and positive for the municipality. In this case following the individual cohort shows an effect on natives which is less positive than following the municipality. The take away, however, is that the difference is not significant, and we will return to the lower employment of the cohort in the latest years in section 5.3.2.

A final thing to notice in these difference-in-difference estimates of Figure 4 is that the pre-1994 treatment-control difference for all outcomes (except one) are not significantly different from 0 . This is reassuring as it shows that there is no pre-event trend in native labor market performances. Let us emphasize that these estimated transitions, especially those following a cohort of individuals are, to the best of our knowledge, really new in this literature. In part because the use of individual panel data covering all native workers is new, in part because it is hard to identify an immigration episode that has a clear beginning, that is randomly allocated and continued over time, it has been hard to analyze the short and long run transition in response to immigration. Figure 4 provides the first analysis of this type in the literature.

The magnitudes of the positive effects estimated for the medium-long run in Table A.1 are somewhat larger than (but comparable to) those estimated in the panel regression. After nine years from 1994, in year 2003, the difference in the share of refugee-country immigrants between treated and non-treated municipalities was about 1.1 percent of the labor force (see Table 1). The estimated effect on the wage 
of less skilled natives was a positive 2.4 percent. This implies a wage elasticity of 2.2 . The within establishment estimates of those elasticities was 1.6 while the estimates across municipalities were 1.8 in the panel regression (Table 6). The difference can be interpreted as the difference between a short and long run elasticity as the panel regression identifies the effect within spells while the difference-in-difference follows the cohort over 18 years. Overall both approaches capture a significant and large effect of refugee-country immigrants on less skilled native workers.

\subsubsection{Effects on out-of-employment Natives}

One form of crowding out of native unskilled workers that could still elude our analysis is represented by the possibility that refugee-country immigrants made it harder for unskilled natives who were not employed to find a job. The differencein-difference analysis has considered, so far, only people who were employed in year 1994, and it does not show the potential effect on native unskilled who were not employed but could enter employment. If those (rather than the incumbents) were "crowded out" by immigrants we need an alternative approach to find it out. In Figure 5 we address this issue. The two panels (A and B) in the figure show the treatment-control difference in employment (measured as fraction of year worked) considering only people in working age who were not employed as of 1994 (but not permanently disabled). As in Figure 4, the left panel follows the cohort of individuals across municipalities while the right panel measures the response of those non-employed following a municipality. Both graphs show that native individuals who were non-employed in 1994 were more likely to supply labor after 1994 if they were in the highly exposed municipalities than if they were in the less exposed but the effect is not significant for the cohort.

The wave of refugee-country immigrants crowded in (rather than out) native unskilled workers in regions with high exposure relative to regions with low exposure. While for the cohort analysis the standard error reported in Figure 5 is large, the point estimates imply that natives who were initially non-employed in regions with high immigrant exposure were on average employed for $10 \%$ more hours than those in municipalities with low exposure, six to ten years after 1994. This is reasonable if we think that most of those less skilled natives out of job in 1994 were young and would find jobs in occupations with high communication-cognitive content, rather than manual, which are complement to the manual skills provided by refugee-country immigrants. This is also consistent with the effects on young workers described 
below.

To gain further insight in the native labor market dynamic effects of refugeecountry immigrants we consider in Figure 6 and 7 two partitions of the native low skilled labor force, and we present the estimates for the specifications following a cohort. First, in Figure 6 we consider young and old workers. Those who were 21 to 46 years old in 1994 are considered "young" and those who were 47 to 61 are considered "old". The older workers all turned 60 within the last years of the transitions and thereby a large group of them became eligible for early retirement pension ("efterløn"). The second dimension we consider is the tenure of workers in the establishment as of 1994. We call "low tenure" those workers with less than the average tenure in our sample (4.35 years in the same establishment) and "high tenure" those with more average tenure. In both cases we expect that the group of young, low-tenure workers had lower costs and more opportunities to upgrade specialization and change their occupation because they had less specific human capital and higher potential benefits from re-qualifying themselves. If the opportunity of wage gains from immigration is in part linked to the ability of upgrading and increasing one's specialization and skills, then young workers with low tenure should be the group better positioned to take advantage of it.

\subsubsection{Effects for Different Groups of Natives}

Figure 6 shows the dynamics for the treatment-control differences in occupational complexity (panel A and B), hourly wage (panel C and D) and fraction of the year worked (panel E and F), separately for young (left panels) and for old (right panels) unskilled native individuals. Figures 7 shows the dynamics for the same outcomes for low tenure (left panel) and high tenure (right panel) unskilled native. The results strongly confirm our hypothesis and are consistent with costs and incentives of upgrading. The young and low-tenure native low skilled workers were those who responded to immigration with stronger transitions towards higher occupational complexity in highly exposed municipalities (panel A). This implies larger hourly wage gains (panel C) and no clear employment change for them (panel E). To the

contrary old and high-tenure workers exhibit much less change in skill in response to high exposure (panel B) and essentially no wage increase as consequence of immigrants (panel D). In terms of employment, while old and high tenure workers did not seem to suffer displacement in the first 5-10 years, in the long run (12-15 years after 1994) they seem to have a lower propensity to work in highly exposed 
municipalities. This may be the result of early retirement, for those who could not upgrade their skills and suffered somewhat from the immigrant competition. The decline observed in labor supply after 10-plus years from the event can be a mild long run displacement effect of immigrants concentrated on older less educated natives as some of them are pushed into early retirement. Overall, the largest benefit from immigration accrued to young, low-tenure workers who upgraded their careers towards more complex occupations, complementary to immigrant skills. Their upgrade is evident from wage increase and it may have required some further training, that is consistent with the small (however insignificant) negative effect on fraction of year employed.

\subsection{Cumulated Effects}

Table 8 reports the estimated effects of an increase in refugee-country immigrants by one percentage point of employment on cumulated native outcomes over 14 years (1995-2008). The estimates are based on equation (3). The first line reports the cumulated impact on employment. The second and third rows report the effect on the length of employment in the initial establishment and in new establishments. The fourth and fifth rows show the length of employment in the same and new municipalities. The last three rows show the effects on the length of cumulated unemployment, the length of cumulated self-employment and on the present discounted value of annual earnings.

Column 1 of Table 8 shows the estimated coefficient on the low skilled native labor force while column 2 and 3 separate outcomes for young and old individuals and columns 4 and 5 show outcomes for low and high tenure individuals. The coefficients in the first row imply that less educated native workers in municipalities receiving an increase in immigrants equal to one percentage point of the labor force experienced a non-significant decline in cumulated employment (over 14 years) by three percent of one work-year, namely 1.3 working weeks. ${ }^{33}$ Hence, refugee-country immigration did not have any significant effect on cumulative employment of less educated natives. Similarly, immigration did not affect the cumulative time spent as unemployed (sixth row) or the probability of moving into self-employment (seventh row). The effects on these variables are also negligible for each sub-group considered in columns 2-5, confirming no evidence of cumulated crowding out of employment

\footnotetext{
${ }^{33}$ We are using 46 weeks as the usual full-time work-year for a Danish worker.
} 
or push into unemployment.

Not very significant is also the effect of immigration on the probability that native workers move out of the initial establishment. To the contrary, a higher inflow of refugee-country immigrants make it more likely for natives to move out of the municipality. On average unskilled natives spent 13-14 working weeks less in the original municipality and they spent that time in a new municipality, over the 14 years following 1994 if they started in a more exposed municipality. Such an effect was even stronger for young workers (whose mobility costs were lower and benefits higher). They spent 23 fewer weeks in the current municipality if they were in a high exposed areas as of 1994. Low tenure workers had also somewhat larger effects than high tenure ones. Thus, the cumulated regressions show that cross-municipality mobility of natives was positively affected by refugee-country immigration.

\section{Discussion and Conclusions}

In this paper we use rich longitudinal data and an exogenous increase in the supply of immigrants from refugee-sending countries to identify the effect of unskilled immigration on the labor market outcomes of low skilled natives. We estimated the short and long run effects of this supply shift on native workers specialization, wages, mobility and employment. The fact that our data allow us to follow every single worker in Denmark and the high quality of the register information imply high reliability. It also implies, for the first time to our knowledge, that we can analyze details about the individual response of native workers within and across establishments and municipalities. The novelty of our identification strategy is that a refugee dispersal policy, in place between 1986 and 1998 in Denmark, produced a distribution of refugees across municipalities unrelated to labor demand. Subsequent large migration flows added significant variation to this exogenously dispersed migrant supply and we use it to estimate its effects on natives.

We find robust evidence that less skilled native workers responded to refugeecountry immigration, mainly composed of low-educated individuals in manual-intensive jobs, by increasing significantly their mobility towards more complex occupations and away from manual tasks. Immigration also increased native low skilled wages and made them more likely to move out of the municipality. We do not observe an increased probability of unemployment, nor a decrease in employment for unskilled natives. 
Our approach reveals another new result. By comparing the estimates obtained by following a cohort of native individuals and the estimates obtained by following the average outcome of natives in an area (as done in previous studies using repeated cross sectional data) we find that for wages, employment and specialization of natives the two approaches give similar results in terms of direction and magnitude. Hence, we dispel the idea that area-based analyses are uninformative due to large spillovers of the wage and employment outcomes, as suggested by some studies (e.g. Borjas, 2006; Borjas, Freeman, and Katz, 1997).

We think that this study present analysis of effects of immigrants that are more detailed and better identified than earlier studies in this literature. It produces a more comprehensive picture of the impacts of immigration by tracking occupations, wages and employment of individual natives within and across establishments. We also show the profile of the dynamic adjustment in response to a sustained immigration inflow for native workers and we add a difference-in-difference approach to the usual 2SLS approach used in this literature. We hope that the future analysis of the impact of immigration in several other countries may follow the approach adopted in this paper and improve upon it. 


\section{References}

Aydemir, Abdurrahman and George J. Borjas. 2011. "Attenuation Bias in Measuring the Wage Impact of Immigration." Journal of Labor Economics 29 (1):69-112.

Blau, Francine and Lawrence Kahn. 2012. "Immigration and the Distribution of Incomes." NBER Working Paper No. 18515:Cambridge, MA.

Borjas, George J. 2003. "The Labor Demand Curve Is Downward Sloping: Reexamining the Impact of Immigration on the Labor Market." Quarterly Journal of Economics 118 (4):1359-1374.

- 2006. "Native Internal Migration and the Labor Market Impact of Immigration." Journal of Human resources 41 (2):221-258.

- 2008. Issues in the Economics of Immigration. University of Chicago Press.

- 2014. Immigration Economics. Harvard University Press.

Borjas, George J., Richard B. Freeman, and Lawrence F. Katz. 1997. "How Much Do Immigration and Trade Affect Labor Market Outcomes?" Brookings Papers on Economic Activity :1-90.

Bratsberg, Bernt, Oddbjørn Raaum, and Knut Røed. 2010. "When Minority Labor Migrants Meet the Welfare State." Journal of Labor Economics 28 (3):633-676.

Card, David. 2009. "Immigration and Inequality." American Economic Review: Papers \& Proceedings 99 (2):1-21.

Cohen-Goldner, Sarit and M. Daniele Paserman. 2011. "The Dynamic Impact of Immigration on Natives' Labor Market Outcomes: Evidence from Israel." European Economic Review 55 (8):1027-1045.

Dahl, Christian M., Daniel le Maire, and Jakob R. Munch. 2013. "Wage Dispersion and Decentralization of Wage Bargaining." Journal of Labor Economics 31 (3):501-533.

Damm, Anna Piil. 2009. "Determinants of recent immigrants' location choices: quasi-experimental evidence." Journal of Population Economics 22 (1):145-174. 
D'Amuri, Francesco, Gianmarco I.P. Ottaviano, and Giovanni Peri. 2010. "The Labor Market Impact of Immigration in Western Germany in the 1990's." European Economic Review 55 (4):550-570.

D'Amuri, Francesco and Giovanni Peri. 2014. "Immigration, Jobs, and Employment Protection: Evidence from Europe Before and During the Great Recession." Journal of the European Economic Association 12 (2):432-464.

Docquier, Frédéric, Çağlar Ozden, and Giovanni Peri. 2014. "The labour market effects of immigration and emigration in OECD countries." The Economic Journal 124 (579):1106-1145.

Dustmann, Christian, Tommaso Frattini, and Ian P. Preston. 2013. "The Effect of Immigration along the Distribution of Wages." Review of Economic Studies $80(1): 145-173$.

Dustmann, Christian and Albrecht Glitz. 2011. "How Do Industries and Firms Repond to Changes in Local Labor Supply." CReAM Discussion Paper No. 18/11.

Edin, Per-Anders, Peter Fredriksson, and Olof Åslund. 2004. "Settlement Policies and the Economic Success of Immigrants." Journal of Population Economics $17(1): 133-155$.

Glitz, Albrecht. 2012. "The Labor Market Impact of Immigration: A QuasiExperiment Exploiting Immigrant Location Rules in Germany." Journal of Labor Economics 30 (1):175-213.

Gould, Eric D., Victor Lavy, and M. Daniele Paserman. 2004. "Immigrating to Opportunity: Estimating the Effect of School Quality Using a Natural Experiment on Ethiopians in Israel." 119 (2):489-526.

Hummels, David, Rasmus Jørgensen, Jakob Roland Munch, and Chong Xiang. 2014. "The Wage Effects of Offshoring: Evidence from Danish Matched Worker-Firm Data." American Economic Review 104 (6):1597-1629.

Lewis, Ethan. 2011. "Immigration, Skill Mix, and Capital-Skill Complementarity." Quarterly Journal of Economics 126 (2):1029-1069.

- 2013. "Immigration and Production Technology." Annual Review of Economics 5 (1):165-191. 
Lewis, Ethan and Giovanni Peri. 2015. "Immigration and the Economy of Cities and Regions." Handbook of Regional and Urban Economics 5A.

Longhi, Simonetta, Peter Nijkamp, and Jacques Poot. 2005. "A Meta-Analytic Assessment of the Effect of Immigration on Wages." Journal of Economic Surveys, Wiley Blackwell 19 (3):451-477.

Malchow-Møller, Nikolaj, Jakob Roland Munch, Claus Aastrup Seidelin, and Jan Rose Skaksen. 2013. "Immigrant Workers and Farm Performance: Evidence from Matched Employer-Employee Data." American Journal of Agricultural Economics 95 (4):819-841.

Malchow-Møller, Nikolaj, Jakob Roland Munch, and Jan Rose Skaksen. 2011. "Do Foreign Experts Increase the Productivity of Domestic Firms?" IZA Discussion Paper (No. 6001):1-44.

—. 2012. "Do Immigrants Affect Firm-Specific Wages?" The Scandinavian Journal of Economics 114 (4):1267-1295.

Manacorda, Marco, Alan Manning, and Jonathan Wadsworth. 2012. "The Impact of Immigration on the Structure of Wages: Theory and Evidence from Britain." Journal of the European Economic Association 10 (1):120-151.

Olney, William W. 2013. "Immigration and Firm Expansion." Journal of Regional Science 53 (1):142-157.

Ortega, Francesc and Giovanni Peri. 2013. "Migration, Trade and Income." IZA Discussion Paper No. 7325:1-42.

Ottaviano, Gianmarco I. P. and Giovanni Peri. 2005. "Cities and Cultures." Journal of Urban Economics 58 (2):304-307.

- 2012. "Rethinking the Effect of Immigration on Wages." Journal of the European Economic Association 10 (1):152-197.

Ottaviano, Gianmarco I. P., Giovanni Peri, and Greg C. Wright. 2013. "Immigration, Offshoring and American Jobs." American Economic Review 103 (5):1925-1959.

Parrotta, Pierpaolo, Dario Pozzoli, and Mariola Pytlikova. 2014. "Labor Diversity and Firm Productivity." Review of Economics and Statistics 66:144-179. 
Peri, Giovanni. 2012. "The Effect of Immigration on Productivity: Evidence from U.S. States." Review of Economics and Statistics 94 (1):348-358.

Peri, Giovanni and Chad Sparber. 2009. "Task Specialization, Immigration and Wages." American Economic Journal: Applied Economics 1 (3):135-169.

Peri, Giovanni, Chad Sparber, and Kevin Shih. forthcoming. "STEM workers, H-1B Visas and Productivity in U.S. Cities." Journal of Labor Economics .

Stock, James H. and Motohiro Yogo. 2005. "Testing for Weak Instruments in Linear IV Regression. Chapter 5 in D. W. K. Andrews and J. H. Stock (Eds.)." Identification and Inference in Econometric Models: Essays in Honor of Thomas J. Rothenberg (Cambridge: Cambridge University Press).

Von Wachter, Till, Jae Song, and Joyce Manchester. 2007. "Long-Term Earnings Losses due to Job Separation During the 1982 Recession: An Analysis Using Longitudinal Administrative Data from 1974 to 2004." Columbia University, Department of Economics, Discussion Paper No. 0708-16. 
Figure 1: Foreign born share in Denmark, 1991-2008

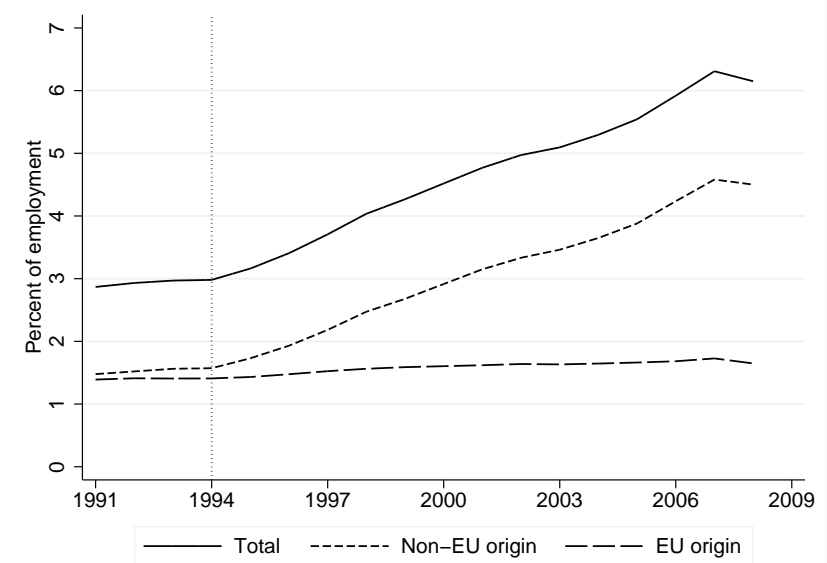

Figure 2: Drivers of non-EU immigration growth, 1991-2008

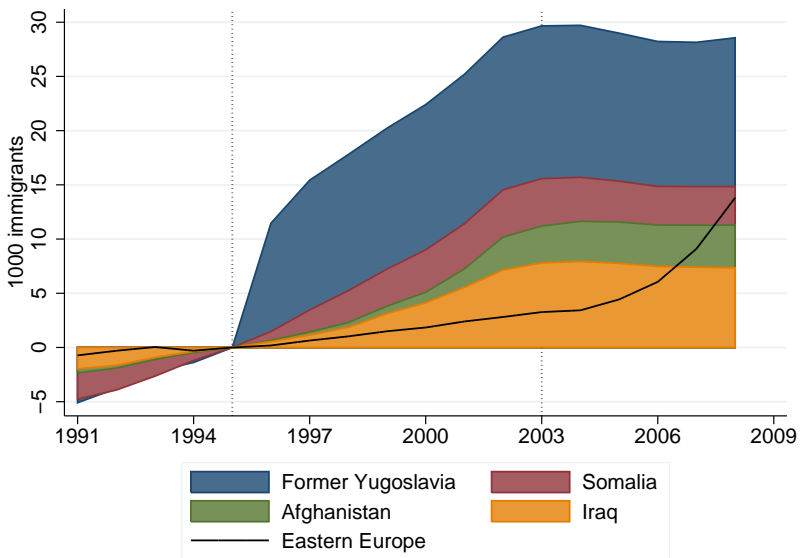

Notes: Growth in immigrant populations since January 1, 1995, from major source countries for refugee inflows between 1986-1998 and from Eastern Europe. 
Table 1: Immigrants' share of employment across municipalities

Panel A. Refugee

$\begin{array}{lllll}\text { Upper quartile } & 0.616 & 0.763 & 1.936 & 2.537\end{array}$

$\begin{array}{lllll}\text { Lower quartile } & 0.224 & 0.230 & 0.820 & 0.987\end{array}$

$\begin{array}{lllll}\text { Difference } & 0.392 & 0.533 & 1.116 & 1.550\end{array}$

Panel B. Total non-EU

$\begin{array}{lllll}\text { Difference } & 2.052 & 2.177 & 4.029 & 4.797\end{array}$

Panel C. EU

$\begin{array}{lllll}\text { Difference } & 0.689 & 0.693 & 1.005 & 1.031\end{array}$

Notes: The actual share of immigrants in percent of employment in the upper and lower quartile of the 1994-2008 difference in predicted refugee share.

Table 2: Skills levels

\begin{tabular}{lrr}
\hline & Refugee & Natives \\
\hline Panel A. Education & & \\
Primary & 0.292 & 0.265 \\
Secondary & 0.104 & 0.059 \\
Vocational & 0.293 & 0.403 \\
Higher & 0.214 & 0.265 \\
Unknown & 0.097 & 0.008 \\
& & \\
Panel B. Occupation & & \\
Most complex & 0.000 & 0.002 \\
Least complex & 0.134 & 0.041 \\
Best paid & 0.003 & 0.030 \\
Least paid & 0.026 & 0.030 \\
\hline
\end{tabular}

Notes: Observations with unknown education in the register likely have foreign education. Occupation groups are the 2-digit ISCO classifications. 
Table 3: Skill content of occupations and change in refugee immigrants share 1994-2008

\begin{tabular}{|c|c|c|c|c|c|}
\hline & \multirow{2}{*}{$\begin{array}{l}\text { Refugee share } \\
1994-2008 \text { dif. }\end{array}$} & \multicolumn{4}{|c|}{ Skill content of occupation } \\
\hline & & Cognitive & Communication & Manual & Complexity \\
\hline \multicolumn{6}{|l|}{ Panel A. Lowest inflow } \\
\hline Managers of small enterprises & -0.003 & 0.666 & 0.677 & 0.432 & 1.136 \\
\hline Legislators and senior officials & 0.001 & 0.897 & 0.989 & 0.303 & 1.828 \\
\hline Skilled agricultural and fishery workers & 0.001 & 0.362 & 0.248 & 0.736 & -0.328 \\
\hline Corporate managers & 0.002 & 0.796 & 0.796 & 0.367 & 1.488 \\
\hline Armed forces & 0.002 & 0.441 & 0.390 & 0.633 & 0.225 \\
\hline \multicolumn{6}{|l|}{ Panel B. Highest inflow } \\
\hline Laborers in mining, construction, manufacturing and transport & 0.022 & 0.215 & 0.156 & 0.769 & -0.783 \\
\hline Drivers and mobile plant operators & 0.023 & 0.352 & 0.265 & 0.810 & -0.322 \\
\hline Other elementary occupations & 0.027 & 0.260 & 0.205 & 0.742 & -0.633 \\
\hline Machine operators and assemblers & 0.036 & 0.276 & 0.146 & 0.790 & -0.655 \\
\hline Sales and services elementary occupations & 0.051 & 0.126 & 0.103 & 0.695 & -1.234 \\
\hline
\end{tabular}

Notes: Complexity index $=\ln (($ Communication+Cognitive $) /$ Manual). The skill content of each occupational grouping (2-digit ISCO) is the population weighted average of the underlying occupations (4-digit ISCO). 
Figure 3: Mean complexity of tasks over time for groups of workers
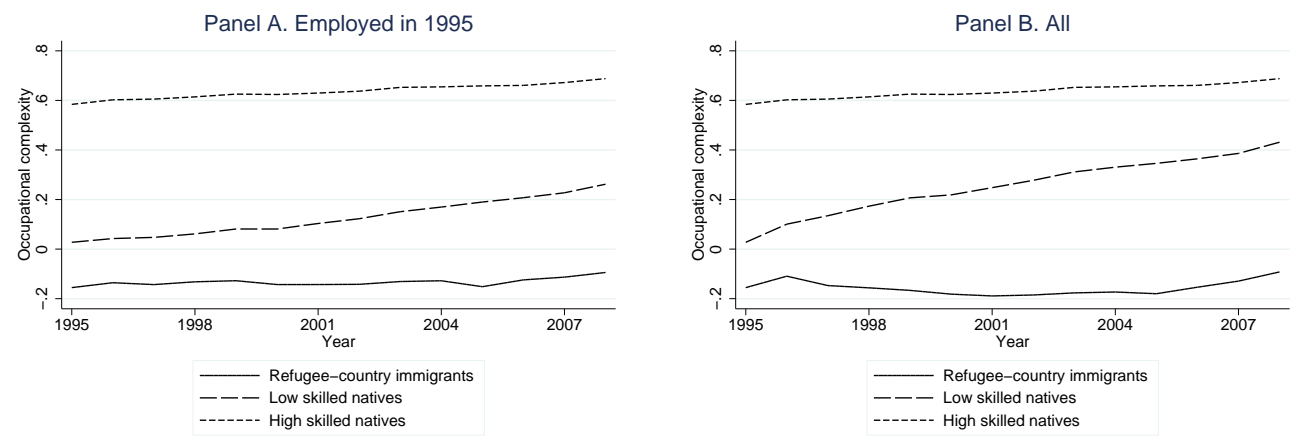

Notes: Each year the figure shows (for three groups) the mean complexity of tasks performed by either those employed in 1995 (Panel A) or all i.e. including new entrants to Danish employment (Panel B). 
Table 4: Summary statistics for employed low skilled

\begin{tabular}{lrr}
\hline & Mean & S.d. \\
\hline Age & 37.77 & 12.26 \\
Labor market experience & 14.68 & 10.13 \\
Job tenure & 4.16 & 5.45 \\
Married & 0.48 & 0.50 \\
Education, primary & 0.63 & 0.48 \\
$\quad$ secondary & 0.15 & 0.36 \\
$\quad$ vocational & 0.16 & 0.37 \\
$\quad$ higher & 0.05 & 0.22 \\
Region, Northern Jytland & 0.11 & 0.31 \\
$\quad$ Central Jytland & 0.23 & 0.42 \\
$\quad$ Southern Denmark & 0.23 & 0.42 \\
$\quad$ Greater Copenhagen Area & 0.28 & 0.45 \\
$\quad$ Zealand & 0.15 & 0.36 \\
Agriculture, fishing and quarrying & 0.03 & 0.16 \\
Manufacturing & 0.23 & 0.42 \\
Electricity, gas and water supply & 0.00 & 0.07 \\
Construction & 0.08 & 0.28 \\
Wholesale and retail sale, hotels and rest. & 0.18 & 0.38 \\
Transport, post and telecommunications & 0.10 & 0.30 \\
Finance and business activities & 0.10 & 0.29 \\
Public and personal services & 0.28 & 0.45 \\
Occupational complexity & & \\
ln(Hourly wagerate) & 0.14 & 0.90 \\
Fraction of year worked & 5.02 & 0.39 \\
\hline Observations & 0.92 & 0.17 \\
\hline
\end{tabular}

Notes: Employed natives 1995-2008. Low skilled is defined as the individual enters the panel. Some low skilled upgrade their education level while at the labor market $(16 \%$ that start out with no post-secondary education obtain a vocational education and $5 \%$ obtain a higher education). 
Table 5: Instrument power and correlation with pre-trends in outcomes for low-skilled natives

\begin{tabular}{lccccc}
\hline & \multicolumn{2}{c}{ 1991-1994 difference in average } & 1994-2008 dif. & $\begin{array}{c}\text { 1994-2008 dif. } \\
\text { in actual }\end{array}$ & $\begin{array}{c}\text { in actual } \\
\text { refugee share }\end{array}$ \\
\hline 1994-2008 dif. in imputed share & -0.609 & 0.664 & -0.152 & 0.030 & $0.858^{* * *}$ \\
& $(0.904)$ & $(0.516)$ & $(0.436)$ & $(0.088)$ & $(0.123)$ \\
F-statistic instrument & 0.45 & 1.65 & 0.12 & 0.12 & 48.88 \\
Observations & 97 & 97 & 97 & 97 & 97 \\
R-squared & 0.37 & 0.64 & 0.81 & 0.74 & 0.79 \\
\hline
\end{tabular}

Notes: ${ }^{* * *} \mathrm{p}<0.001,{ }^{* *} \mathrm{p}<0.01,{ }^{*} \mathrm{p}<0.05$. Each regressions is at the municipality level and weighted by the size of the labor force in the municipality. The table shows correlation of instrument with pre-trends in outcomes for low skilled natives and with actual change in foreign born share. Controls are those listed in Table 4 averaged for each municipality in 1994. 
Table 6: Fixed-effect regressions, low skilled

\begin{tabular}{|c|c|c|c|c|c|c|}
\hline & $(1)$ & $(2)$ & $(3)$ & $(4)$ & $(5)$ & $(6)$ \\
\hline & \multicolumn{2}{|c|}{ Worker-establishment } & \multicolumn{2}{|c|}{ Worker-municipality } & \multicolumn{2}{|c|}{ Worker } \\
\hline & $\mathrm{FE}$ & FE-IV & $\mathrm{FE}$ & FE-IV & $\mathrm{FE}$ & FE-IV \\
\hline \multirow[t]{2}{*}{ Occupational complexity } & 0.255 & 0.259 & $1.310^{*}$ & $3.170^{*}$ & $0.602^{*}$ & $1.340^{* *}$ \\
\hline & $(0.326)$ & $(0.580)$ & $(0.612)$ & $(1.534)$ & $(0.275)$ & $(0.478)$ \\
\hline \multirow[t]{2}{*}{ Manual intensity } & -0.122 & -0.289 & $-0.717^{* *}$ & $-1.947^{* *}$ & $-0.388^{* *}$ & $-0.851^{* * *}$ \\
\hline & $(0.143)$ & $(0.337)$ & $(0.224)$ & $(0.680)$ & $(0.131)$ & $(0.230)$ \\
\hline \multirow[t]{2}{*}{ Communication intensity } & -0.144 & -0.514 & 0.200 & 0.559 & 0.156 & $0.668^{*}$ \\
\hline & $(0.315)$ & $(0.526)$ & $(0.512)$ & $(1.001)$ & $(0.210)$ & $(0.333)$ \\
\hline \multirow{2}{*}{ Cognitive intensity } & 0.327 & 0.144 & $0.821^{*}$ & 1.417 & 0.213 & 0.238 \\
\hline & $(0.198)$ & $(0.488)$ & $(0.407)$ & $(0.855)$ & $(0.148)$ & $(0.233)$ \\
\hline \multirow[t]{2}{*}{ Occupational mobility } & 0.320 & 1.004 & 0.502 & $1.933^{*}$ & $0.931^{* * *}$ & $1.781^{* * *}$ \\
\hline & $(0.295)$ & $(0.785)$ & $(0.412)$ & $(0.983)$ & $(0.214)$ & $(0.457)$ \\
\hline \multirow[t]{2}{*}{ Hourly wage } & $0.620^{*}$ & $1.601^{* *}$ & 0.169 & 0.983 & $0.787^{* *}$ & $1.802^{* *}$ \\
\hline & $(0.265)$ & $(0.507)$ & $(0.351)$ & $(0.601)$ & $(0.300)$ & $(0.642)$ \\
\hline \multirow[t]{2}{*}{ Fraction of year worked } & 0.151 & $0.554^{*}$ & $0.259^{*}$ & $0.794^{* *}$ & $0.408^{* * *}$ & $0.735^{* * *}$ \\
\hline & $(0.129)$ & $(0.262)$ & $(0.106)$ & $(0.287)$ & $(0.066)$ & $(0.101)$ \\
\hline Observations & 1564737 & 1564737 & 1816727 & 1816727 & 1864027 & 1864027 \\
\hline First stage $F$-statistic & & 53.53 & & 58.01 & & 468.87 \\
\hline \multirow[t]{2}{*}{ First stage coefficient } & & $0.551^{* * *}$ & & $0.603^{* * *}$ & & $0.476^{* * *}$ \\
\hline & & $(0.075)$ & & $(0.079)$ & & $(0.022)$ \\
\hline
\end{tabular}

Notes: ${ }^{* * *} \mathrm{p}<0.001,{ }^{* *} \mathrm{p}<0.01,{ }^{*} \mathrm{p}<0.05$. Each entry of the table is the coefficient on the explanatory variable of interest in equation (1) using a sample of employed low skilled natives between 1995 and 2008. The dependent variables (left column) have the same first stage except for occupational complexity that has fewer observations (some missings). Standard errors in parentheses are clustered by initial municipality. 
Table 7: Fixed-effect regressions, high skilled

\begin{tabular}{|c|c|c|c|c|c|c|}
\hline & \multirow{2}{*}{\multicolumn{2}{|c|}{$\begin{array}{c}(1) \quad(2) \\
\text { Worker-establishment }\end{array}$}} & \multirow{2}{*}{\multicolumn{2}{|c|}{$\begin{array}{c}(3) \\
\text { Worker-municipality }\end{array}$}} & $(5)$ & $(6)$ \\
\hline & & & & & \multicolumn{2}{|c|}{ Worker } \\
\hline & $\mathrm{FE}$ & FE-IV & $\mathrm{FE}$ & FE-IV & $\mathrm{FE}$ & FE-IV \\
\hline Occupational complexity & $\begin{array}{l}-0.038 \\
(0.256)\end{array}$ & $\begin{array}{c}0.245 \\
(0.457)\end{array}$ & $\begin{array}{c}0.406 \\
(0.256)\end{array}$ & $\begin{array}{c}1.149^{* *} \\
(0.410)\end{array}$ & $\begin{array}{l}0.288^{*} \\
(0.139)\end{array}$ & $\begin{array}{c}0.477^{*} \\
(0.220)\end{array}$ \\
\hline Manual intensity & $\begin{array}{l}-0.132 \\
(0.112)\end{array}$ & $\begin{array}{l}-0.448 \\
(0.243)\end{array}$ & $\begin{array}{c}-0.308^{*} \\
(0.120)\end{array}$ & $\begin{array}{c}-0.777^{* *} \\
(0.246)\end{array}$ & $\begin{array}{c}-0.237^{* * *} * \\
(0.070)\end{array}$ & $\begin{array}{c}-0.387^{* * *} \\
(0.096)\end{array}$ \\
\hline Communication intensity & $\begin{array}{l}-0.346 \\
(0.224)\end{array}$ & $\begin{array}{l}-0.239 \\
(0.361)\end{array}$ & $\begin{array}{c}0.005 \\
(0.246)\end{array}$ & $\begin{array}{c}0.484 \\
(0.352)\end{array}$ & $\begin{array}{c}0.050 \\
(0.122)\end{array}$ & $\begin{array}{c}0.218 \\
(0.176)\end{array}$ \\
\hline Cognitive intensity & $\begin{array}{l}-0.084 \\
(0.184)\end{array}$ & $\begin{array}{l}-0.447 \\
(0.522)\end{array}$ & $\begin{array}{c}0.101 \\
(0.199)\end{array}$ & $\begin{array}{l}-0.009 \\
(0.396)\end{array}$ & $\begin{array}{c}0.021 \\
(0.111)\end{array}$ & $\begin{array}{l}-0.096 \\
(0.197)\end{array}$ \\
\hline Occupational mobility & $\begin{array}{c}0.106 \\
(0.235)\end{array}$ & $\begin{array}{l}1.301^{*} \\
(0.546)\end{array}$ & $\begin{array}{c}0.395 \\
(0.272)\end{array}$ & $\begin{array}{c}1.944^{* * *} \\
(0.569)\end{array}$ & $\begin{array}{c}0.209 \\
(0.160)\end{array}$ & $\begin{array}{c}0.378 \\
(0.260)\end{array}$ \\
\hline Hourly wage & $\begin{array}{c}0.512^{* * *} \\
(0.148)\end{array}$ & $\begin{array}{c}2.068^{* * *} * \\
(0.452)\end{array}$ & $\begin{array}{c}0.522^{*} \\
(0.203)\end{array}$ & $\begin{array}{c}2.316^{* * *} \\
(0.584)\end{array}$ & $\begin{array}{l}-0.301 \\
(0.381)\end{array}$ & $\begin{array}{l}-0.034 \\
(0.483)\end{array}$ \\
\hline Fraction of yea employed & $\begin{array}{l}-0.083 \\
(0.080)\end{array}$ & $\begin{array}{c}0.178 \\
(0.176)\end{array}$ & $\begin{array}{l}-0.048 \\
(0.073)\end{array}$ & $\begin{array}{c}0.120 \\
(0.166)\end{array}$ & $\begin{array}{l}0.096^{*} \\
(0.040)\end{array}$ & $\begin{array}{c}0.223^{* * *} \\
(0.060)\end{array}$ \\
\hline Observations & 2860183 & 2860183 & 3125934 & 3125934 & 3160757 & 3160757 \\
\hline First stage $F$-statistic & & 63.28 & & 68.02 & & 294.85 \\
\hline First stage coefficient & & $\begin{array}{c}0.563^{* * *} \\
(0.071)\end{array}$ & & $\begin{array}{c}0.607^{* * *} \\
(0.074)\end{array}$ & & $\begin{array}{c}0.495^{* * *} \\
(0.029)\end{array}$ \\
\hline
\end{tabular}

Notes: ${ }^{* *} \mathrm{p}<0.001,{ }^{* *} \mathrm{p}<0.01,{ }^{*} \mathrm{p}<0.05$. Each entry of the table is the coefficient on the explanatory variable of interest in equation (1) using a sample of employed high skilled natives between 1995 and 2008 . The dependent variables (left column) have the same first stage except for occupational complexity that has fewer observations (some missings). Standard errors in parentheses are clustered by initial municipality. 
Figure 4: Treatment-control estimated differences in outcomes, low skilled
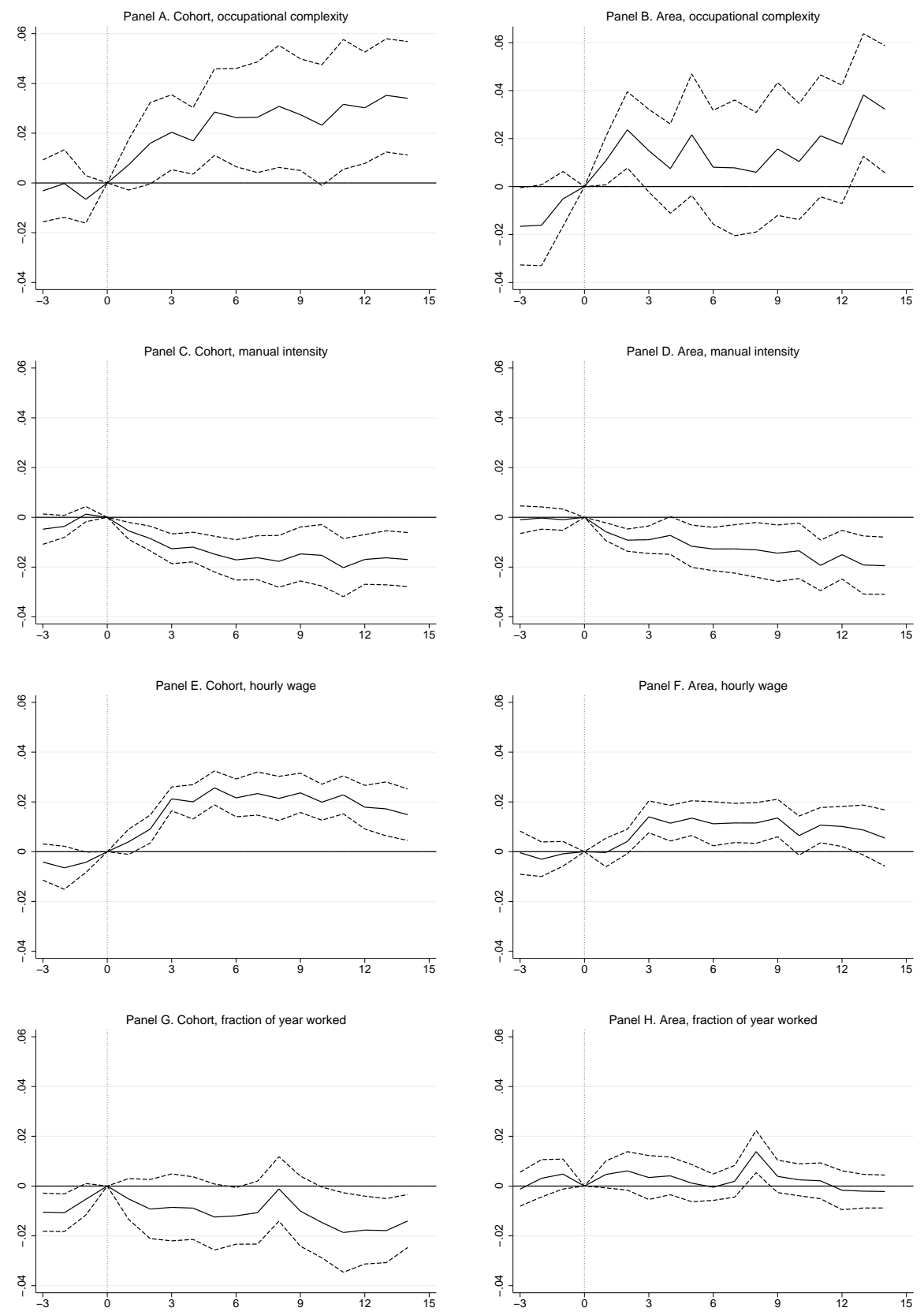

Notes: Parameter estimates (-) and 95\% confidence limits (- - -) on the interaction terms of immigration exposure and year dummies in equation (2) using a strongly balanced panel of low skilled natives employed in 1994. All control variables are either specific to the worker in 1994 (cohort) or the actual values for the worker (area). Accordingly, standard errors are clustered at the 1994-municipality for the cohort regressions and at the actual municipality for the area regressions. 
Figure 5: Treatment-control estimated differences in employment for those not employed in 1994, low skilled
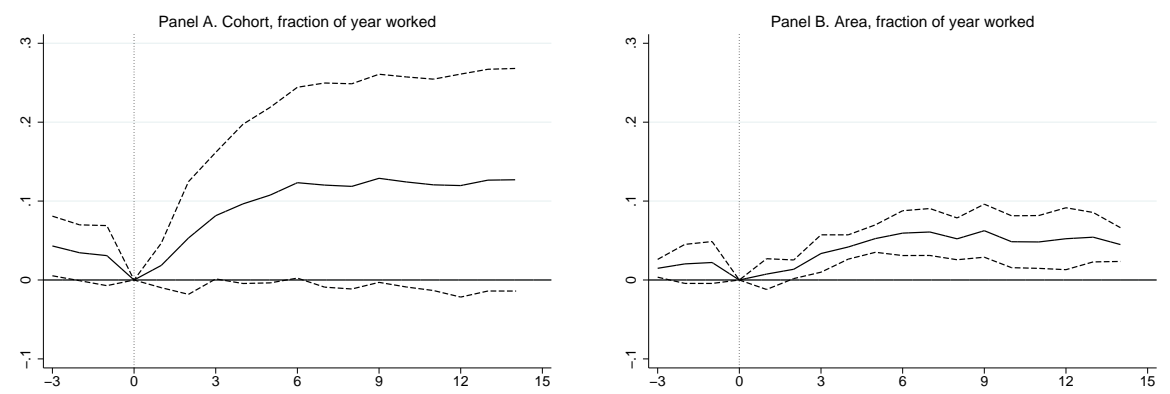

Notes: Parameter estimates (-) and 95\% confidence limits (- - -) on the interaction terms of immigration exposure and year dummies in equation (2) using a strongly balanced panel of low skilled natives not employed in 1994. All control variables are either specific to the worker in 1994 (cohort) or the actual values for the worker (area). Accordingly, standard errors are clustered at the 1994-municipality for the cohort regressions and at the actual municipality for the area regressions. No one in this figure (the non-employed in November 1994) has firm tenure and industry affiliation in November 1994 and these variables are therefore left out of the regression. 
Figure 6: Treatment-control cohort estimated differences in outcomes by age group, low skilled
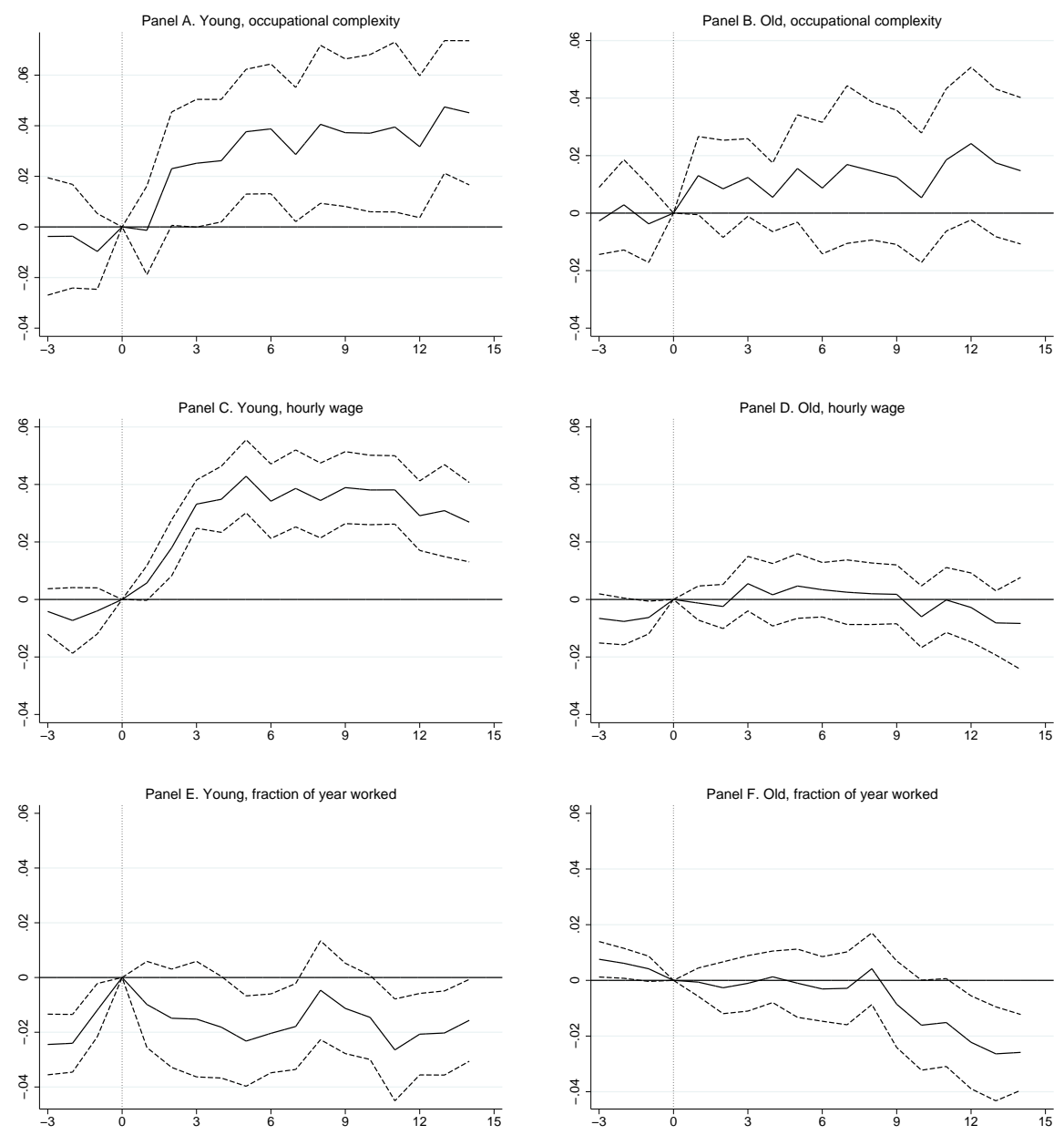

Notes: Parameter estimates (-) and 95\% confidence limits (- - -) on the interaction terms of immigration exposure and year dummies in equation (2) using a strongly balanced panel of low skilled natives employed in 1994. Standard errors are clustered at the 1994-municipality. Young (old) are those aged 21-36 (37-51) in 1994 . 
Figure 7: Treatment-control cohort estimated differences in outcomes by tenure group, low skilled
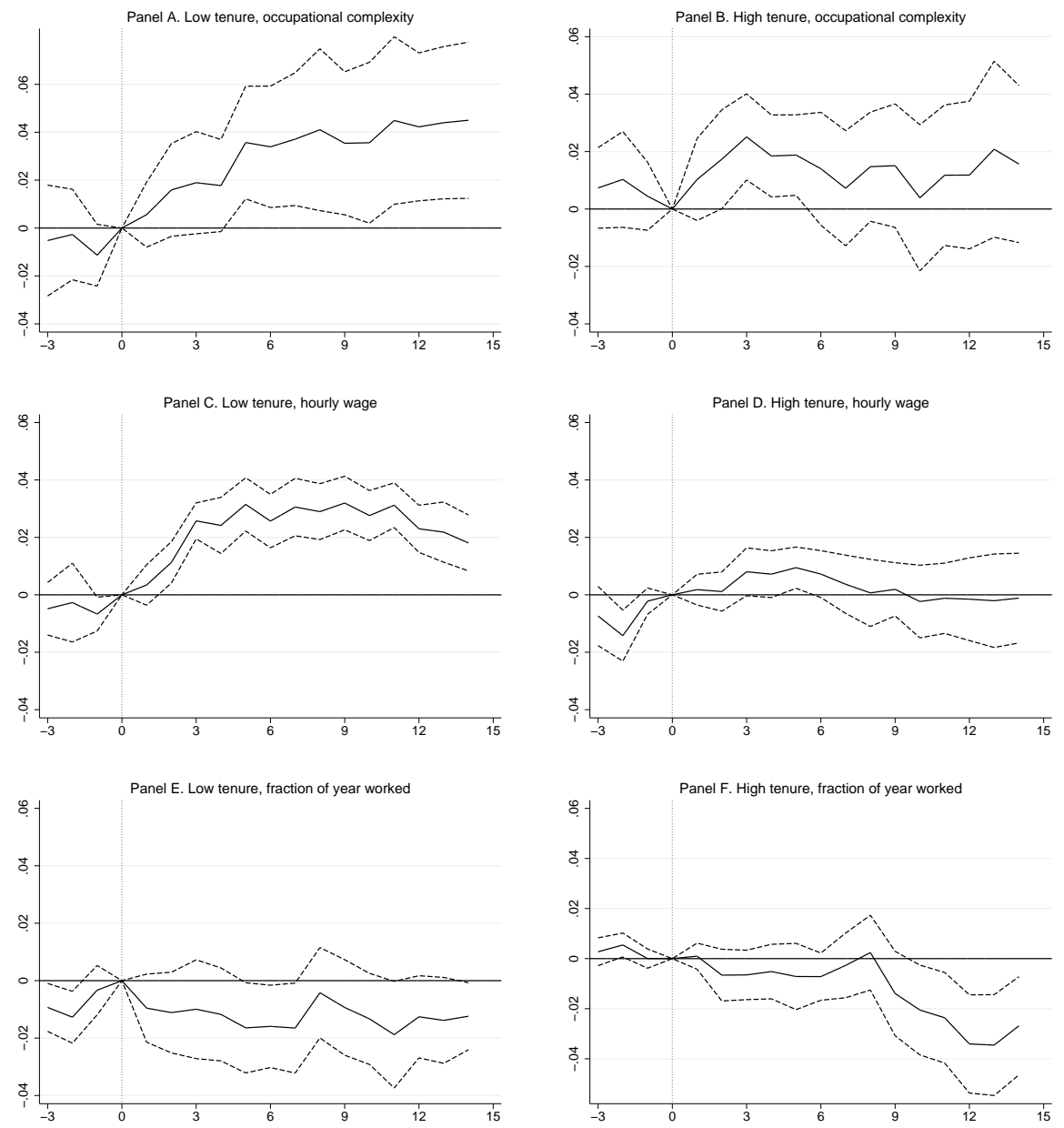

Notes: Parameter estimates (-) and 95\% confidence limits (- - ) on the interaction terms of immigration exposure and year dummies in equation (2) using a strongly balanced panel of low skilled natives employed in 1994. Standard errors are clustered at the 1994-municipality. Low (high) tenure are those with less than (at least) 4.35 years in the firm in 1994. 
Table 8: The cumulative effect on employment and mobility for low skilled, 1995-2008

\begin{tabular}{lccccc}
\hline & All & Young & Old & Low tenure & High tenure \\
\hline Cumulative employment & -3.318 & -2.633 & 1.681 & -2.848 & -2.816 \\
& $(6.886)$ & $(6.761)$ & $(6.389)$ & $(8.153)$ & $(5.668)$ \\
- same establishment & -5.881 & -8.848 & 0.449 & 4.699 & $-23.975^{*}$ \\
& $(5.363)$ & $(5.457)$ & $(6.870)$ & $(4.311)$ & $(10.706)$ \\
- new establishment & 2.563 & 6.215 & 1.233 & -7.548 & $21.159^{*}$ \\
& $(6.250)$ & $(7.156)$ & $(6.883)$ & $(7.591)$ & $(9.621)$ \\
- same municipality & $-29.516^{*}$ & $-52.280^{* *}$ & 1.557 & $-30.123^{*}$ & $-25.294^{*}$ \\
& $(12.006)$ & $(16.921)$ & $(7.133)$ & $(13.096)$ & $(10.734)$ \\
- new municipality & $26.198^{* *}$ & $49.647^{* * *}$ & 0.124 & $27.275^{* *}$ & $22.478^{*}$ \\
& $(9.284)$ & $(13.670)$ & $(6.325)$ & $(9.957)$ & $(9.928)$ \\
Cumulative unemployment & 1.801 & 0.439 & 0.739 & 0.910 & 3.753 \\
Cumulative self-employment & $(3.551)$ & $(3.602)$ & $(3.347)$ & $(3.936)$ & $(3.091)$ \\
& -1.797 & $-3.560^{*}$ & -1.122 & -3.835 & 0.964 \\
PDV of annual earnings & $(1.622)$ & $(1.518)$ & $(2.021)$ & $(2.067)$ & $(1.357)$ \\
& 0.984 & 1.989 & 0.854 & 0.841 & 1.433 \\
Observations & $(1.120)$ & $(1.073)$ & $(1.257)$ & $(1.296)$ & $(1.021)$ \\
First stage $F$-statistic & & & & & \\
\hline
\end{tabular}

Notes: $* * * \mathrm{p}<0.001,{ }^{* *} \mathrm{p}<0.01,{ }^{*} \mathrm{p}<0.05$. Each entry of the table is the coefficient on the explanatory variable of interest (immigration exposure) in equation (3) using a strongly balanced panel of natives employed in 1994. Standard errors in parentheses and $F$-statistic for significance of excluded instrument are clustered at the 1994-municipality. The final row is the discounted sum of the 1995-2008 earnings stream using a four percent annual discount rate. 